Review

\title{
Groundbreaking Anticancer Activity of Highly Diversified Oxadiazole Scaffolds
}

\author{
Alessandra Benassi $\mathbb{D}^{\mathbb{D}}$, Filippo Doria $\mathbb{D}$ and Valentina Pirota * $\mathbb{C}$ \\ Chemistry Department, University of Pavia, Via Taramelli 10, 27100 Pavia, Italy; \\ alessandra.benassi01@universitadipavia.it (A.B.); filippo.doria@unipv.it (F.D.) \\ * Correspondence: valentina.pirota@unipv.it
}

Received: 30 October 2020; Accepted: 16 November 2020; Published: 18 November 2020

\begin{abstract}
Nowadays, an increasing number of heterocyclic-based drugs found application in medicinal chemistry and, in particular, as anticancer agents. In this context, oxadiazoles-five-membered aromatic rings-emerged for their interesting biological properties. Modification of oxadiazole scaffolds represents a valid strategy to increase their anticancer activity, especially on 1,2,4 and $1,3,4$ regioisomers. In the last years, an increasing number of oxadiazole derivatives, with remarkable cytotoxicity for several tumor lines, were identified. Structural modifications, that ensure higher cytotoxicity towards malignant cells, represent a solid starting point in the development of novel oxadiazole-based drugs. To increase the specificity of this strategy, outstanding oxadiazole scaffolds have been designed to selectively interact with biological targets, including enzymes, globular proteins, and nucleic acids, showing more promising antitumor effects. In the present work, we aim to provide a comprehensive overview of the anticancer activity of these heterocycles, describing their effect on different targets and highlighting how their structural versatility has been exploited to modulate their biological properties.
\end{abstract}

Keywords: oxadiazoles; bioactive heterocyclics; anticancer agents; telomerase; Carbonic anhydrase; histone deacetylase; kinases; tubulin; DNA; G-quadruplex

\section{Introduction}

Heterocyclic compounds are recognized as intriguing scaffolds to incorporate in bioactive small molecules, due to the crucial role that heteroatoms cover in physiological processes. Indeed, more than $85 \%$ of biologically active compounds bear at least one heterocyclic moiety [1].

In this context, oxadiazoles are small five-membered heterocycles, composed of two carbon, one oxygen, and two nitrogen atoms, which attracted a lot of interest in different scientific disciplines: from medicine $[2,3]$ and agrochemistry $[4]$ to materials science $[5,6]$.

Their aromatic flat surface is effective in the target binding, through $\pi$-stacking interactions, or to properly outdistance the substituents according to a specific orientation [7]. Depending on nitrogen atoms position, oxadiazoles exist in four different regioisomeric forms (Figure 1): 1,2,3-, 1,2,4-, 1,2,5-, and 1,3,4-oxadiazoles.<smiles>[R]c1nnoc1[R]</smiles><smiles>[R]Cc1noc([R])n1</smiles><smiles>[R]c1nonc1[R]</smiles><smiles></smiles>

$1,2,3$ - oxadiazole

1,2,4 - oxadiazole

1,2,5 - oxadiazole

1,3,4 - oxadiazole

Figure 1. Chemical structures of the four isomers of the oxadiazole. 
During the last decades, the design of new oxadiazole-based scaffolds accelerated in medicinal chemistry, bringing most of these compounds to the preclinical stage or, even, to commercialization. Among these, the most commercially available drugs are Oxolamine, a cough suppressant [16], Ataluren, indicated for the treatment of Duchenne muscular dystrophy [17] and cystic fibrosis [18], Butalamine, a vasodilator, Proxazole, a drug for functional gastrointestinal disorders, Fasiplon, an anxiolytic drug [19], Raltegravir, an antiretroviral drug used to treat HIV [20], which has been recently proposed as repurposing drug against SARS-COV-2 [21], as well as the antiviral Pleconaril selected for the SARS-COV-2 spike protein [22] (Figure 2). Equally well known is Zibotentan, an anticancer drug in late-stage clinical trials (www.ClinicalTrials.gov Identifier: NCT00554229), which is a candidate in development by AstraZeneca (Figure 2).<smiles>CCN(CC)CCc1nc(-c2ccccc2)no1</smiles>

Oxolamine<smiles>O=C(O)c1cccc(-c2noc(-c3ccccc3F)n2)c1</smiles>

Ataluren<smiles>CCCCN(CCCC)CCNc1nc(-c2ccccc2)no1</smiles>

Butalamine

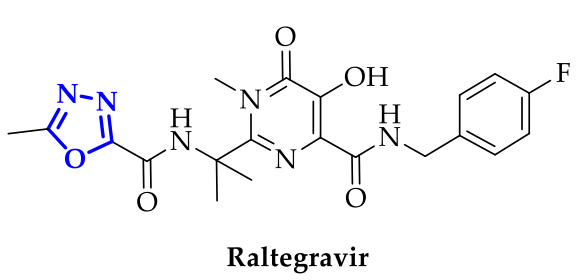<smiles>CCc1c(OC)nc2nc(-c3noc(C)n3)cn2c1C</smiles>

Fasiplon<smiles>[R10]Oc1nc(C)cnc1NS(=O)(=O)c1cccnc1-c1ccc(-c2nnco2)cc1</smiles>

Zibotentan

Figure 2. Structures of some of the most famous ligands bearing oxadiazole moiety.

Considering the meaningful social impact of cancer, due to the incessant raise incidence, with resistance towards existing drugs and severe side effects, the need to develop novel anticancer drugs is compelling.

Herein, we present a comprehensive overview of the most recent small molecules bearing oxadiazoles moieties, which act as anticancer agents. This work aims to highlight the biological targets, if known, with whom these small molecules interact to achieve their antiproliferative effects.

\section{Enzyme Interactions}

Tailor-made inhibitors for a specific enzyme result in extremely interesting as anticancer agents because of the high specificity of enzymatic activity [23-25]. Starting from this consideration, here we reported the results obtained in enzyme inhibition by using oxadiazoles as biological ligands.

\subsection{Specific Inhibitors of Telomerase}

Telomerase, a ribonucleoprotein enzyme, maintains the length of chromosomes catalyzing the addition of hexameric telomeric repeats (TTAGGG) to the $3^{\prime}$-end of the template strand of DNA. It follows that its role is necessary for the long-term viability of the cells.

Whereas its activity is negligible in most human somatic cells, telomerase is overexpressed in around $90 \%$ of cancer cells, actively contributing to their immortality and tumor genesis [26]. Therefore, inhibition of telomerase is considered a very interesting approach for anticancer drug design. 
In this context, Zheng et al. synthesized a family of twenty-one 2-chloropyridine derivatives bearing 1,3,4-oxadiazole units, differently substituted in position five, to evaluate their antitumor potency. Sixteen of these compounds showed a remarkable antiproliferative activity against SGC-7901 gastric cancer cells, eight with $\mathrm{IC}_{50}$ values comparable to the positive control (5-Fluorouracil) and eight $50 \%$ lower [27]. Among them, the best results were reached by compounds $\mathbf{1}$ and $\mathbf{2}$ (Figure 3), which exhibited the most potent activity $\left(\mathrm{IC}_{50}=1.61 \pm 0.06 \mu \mathrm{g} / \mathrm{mL}\right.$ and $\mathrm{IC}_{50}=2.56 \pm 0.11 \mu \mathrm{g} / \mathrm{mL}$, respectively). Moreover, 1 showed a specific telomerase inhibitory activity $\left(\mathrm{IC}_{50}=2.30 \pm 0.07 \mu \mathrm{M}\right)$ identified by TRAP assay on a SGC-7901 cell extract, comparable to the positive control ethidium bromide ( $\mathrm{IC}_{50}=2.50 \pm 0.23 \mu \mathrm{M}$ ) [27]. This result prompted the authors to carry out molecular docking studies (GLIDE protocol, Schrodinger Inc.) to elucidate the specific interactions between the compound and ATP binding site of the enzyme. Using the 3DU6.pdb telomerase structure deposited [28], they demonstrated the implication of three hydrogen bonds: two between the hydroxyl group of $\mathbf{1}$ and the amino group of Lys249 as well as oxygen atom of Asp344, the third between Gly391 residue and the oxygen atom of methoxyl group [27].
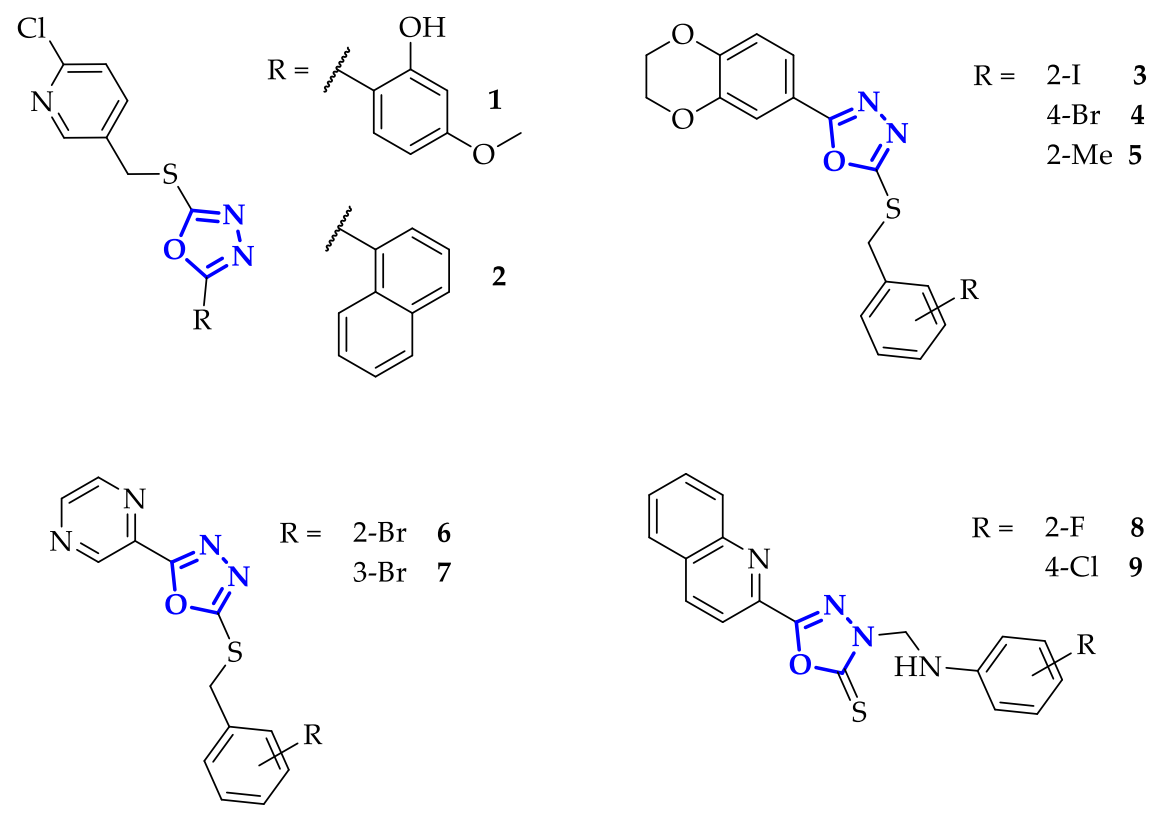

Figure 3. Chemical structures of 1,3,4-oxadiazole derivatives identified as good telomerase inhibitors.

A very similar study was conducted by Zhang et al. on a series of 1,3,4-oxadiazole derivatives possessing a 1,4-benzodioxan moiety, previously recognized as a fundamental unit to guarantee good bioavailability and low cytotoxicity in other potential anticancer drugs [29].

All the synthesized compounds revealed a broad-spectrum antitumor activity against HepG2, HeLa, SW1116, and BGC823 cell lines according to standard MTT-based colorimetric assay, with an $\mathrm{IC}_{50}$ value at least $55 \%$ lower than positive control $\left(\mathrm{IC}_{50}=110 \mu \mathrm{M}\right.$ for 5-Fluorouracil). The best antiproliferative effectiveness was obtained on HepG2 line by compounds $\mathbf{3}$ and $\mathbf{4}$ (Figure 3) with $\mathrm{IC}_{50}$ values of $7.21 \mu \mathrm{M}$ and $8.54 \mu \mathrm{M}$, respectively. Besides, sixteen of these molecules displayed a telomerase inhibitory activity $\left(\mathrm{IC}_{50}\right.$ concentration range of $1.27 \pm 0.05-5.89 \pm 0.35 \mu \mathrm{M}$ evaluated via TRAP-PCR-ELISA assay) against SW1116 cancer cell higher than positive control Staurosporine $\left(\mathrm{IC}_{50}=8.32 \pm 0.08 \mu \mathrm{M}\right)$. Among these, 5 showed the highest telomerase inhibition, and therefore the simulation of its binding mode on ATP binding site of telomerase (3DU6.pdb) was predicted by molecular docking studies (AutoDock software package 4.0) [29]. The oxadiazole is involved in a hydrogen bond with the amino residue of Lys372, while 1,4-benzodioxan unit gets a second hydrogen bond with hydrogen of Lys406. Moreover, three $\pi$-cation interactions shaped, two between Lys406 and 
1,4-benzodioxan as well as the other benzene ring, while the third was provided from oxadiazole and Lys372 [29].

To extend their work, the same group synthesized and studied a new family of 1,3,4-oxadiazole ligands containing a pyrazine moiety [30]. Biological activity was evaluated on the same four cancer cell lines, highlighting a broad-spectrum of antiproliferative effects. In this case, the best results were obtained on HepG2 and SW1116 cells with compounds 6 and 7 (HepG2, IC $50=4.22-5.79 \mu \mathrm{M}$; SW1116, $\mathrm{IC}_{50}=2.46-5.06 \mu \mathrm{M}$; Figure 3), which are more or equally efficient than positive control Staurosporine (HepG2, $\mathrm{IC}_{50}=6.73 \mu \mathrm{M}$; SW1116, $\mathrm{IC}_{50}=4.95 \mu \mathrm{M}$ ). Besides, their telomerase inhibition against HepG2 cells was slightly higher than the positive control $\left(\mathrm{IC}_{50}\right.$ of around $3.5 \mu \mathrm{M}$ versus $4.14 \mu \mathrm{M})$, demonstrating that their antiproliferative activity was strictly related to telomerase inhibition. In particular, it has been predicted that compound $\mathbf{6}$ interacts with telomerase binding site through five hydrogen bonds: three involved oxadiazole moiety and Arg194 as well as Gln308 residues, the other two were correlated to pyrazine's nitrogen atom and Lys189 [30]. Outcomes from molecular docking (by Discovery Studio 3.1) emphasized the positive involvement of 1,3,4-oxadiazole units in the enzyme binding and inhibition, further evidencing their specificity and potency.

A wide-ranging antitumor activity was subsequently attained by conjugating quinoline to 1,3,4-oxadiazole [31]. Among the compounds synthesized by Sun et al., seven showed in vitro anticancer activity higher than 5-fluorouracil against human tumor HepG2, SGC-7901, and MCF-7 cell lines. Distinctly, 8 and 9 (Figure 3 ) revealed the best $\mathrm{IC}_{50}$ values, with exceptional effects against HepG2 line $\left(\mathrm{IC}_{50}=1.2 \pm 0.2-0.8 \pm 0.2 \mu \mathrm{M}\right.$ versus 5 -fluorouracil $\left.\mathrm{IC}_{50}=21.9 \pm 1.4 \mu \mathrm{M}\right)$. Their effectiveness was closely related to telomerase inhibitory activity, as demonstrated by TRAP-PCR-ELISA assay. $\mathrm{IC}_{50}$ values were one order magnitude lower ( $\mathrm{IC}_{50}=0.8$ and $0.9 \mu \mathrm{M}$ for 8 and 9 respectively) than the one achieved with Staurosporine $\left(\mathrm{IC}_{50}=8.3 \mu \mathrm{M}\right)$ [31]. While for 8, the interaction with the telomerase binding site is unconnected to the presence of oxadiazole unit, the 1,3,4-oxadiazole in 9 is responsible for two H-bonds that involved Gln308 and Arg194 residues, as predicted by automated docking studies [31].

\subsection{Selective Inhibition of Carbonic Anhydrase Isoforms}

Human carbonic anhydrases (CA) comprise a family of metalloenzymes that catalyze the reversible hydration of carbon dioxide to hydrogen carbonate with the release of a proton. This biological process maintains acid-base balance in the intra- and extracellular regions in several tissue and organs [32].

Among them, the membrane-bound CA IX and CA XII are overexpressed in solid and metastatic tumors, playing an important role in tumorigenesis, cancer cell signaling, and survival under hypoxic conditions and acidic extracellular environment. For these features, the selective inhibition of specific CA isoforms became a groundbreaking target in anticancer therapy.

Krasavin et al. synthesized, in 2018, a promising series of CA inhibitors based on primary sulfonamide-tagged 1,2,4-oxadiazole core. Through $\mathrm{CO}_{2}$ hydration stopped-flow biochemical assay, they compared the ligands interactions with two cytosolic CA isoforms (I and II) and two membrane-bound CA (IV and IX) [33]. Several of these compounds revealed a marked selectivity in CA II and CA IX inhibition, classical targets for treatment of glaucoma-related intraocular hypertension and solid tumors, respectively. Nineteen compounds inhibited CA II in a sub-nanomolar range, among which 10 (Figure 4) shown the best Ki value equal to $0.48 \mathrm{nM}$, twenty-five times lower than positive control acetazolamide $(12.1 \mathrm{nM})$. CA IX inhibition was reached at low-nanomolar range by fourteen compounds, with the best result derived from $\mathbf{1 1}(\mathrm{Ki}=1.2 \mathrm{nM}$; Figure 4) significantly lower than Acetazolamide (25.8 nM) [33]. Despite the fact that these compounds did not show a univocal selectivity, the cellular localization of CA II and CA IX is so different that it was not a real disadvantage. Docking studies predicted that 1,2,4-oxadiazole unit was not involved in crucial direct interaction with the targets, except for the possible presence of H-bond with Gln92. Anyhow, it properly orients its substituents allowing them specific interactions with the targets. 

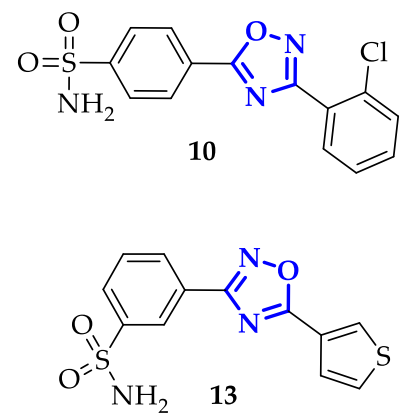
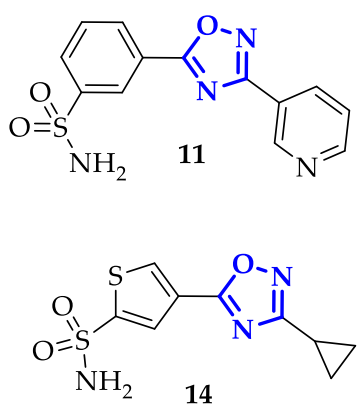
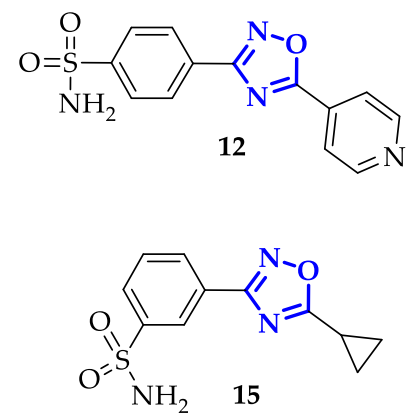

Figure 4. 1,2,4-oxadiazoles derivatives that showed a good inhibition of carbonic anhydrase IX and XII isoforms.

Encouraged by these results, the authors developed a new family of 1,2,4-oxadiazole derivatives, containing aryl-sulfonamide units, which were effective against not only to CA II and CA IX in a sub-nanomolar range but also to CA XII in a nanomolar range [34]. By $\mathrm{CO}_{2}$ hydration stopped-flow biochemical assay, they compared again the inhibitory effects on CA I and II versus the two cancer-related CA isoforms IX and XII. Among the twenty-four compounds, twenty retained sub-nanomolar to low nanomolar inhibitory potency against CA II isoform, with Ki values of $0.3 \mathrm{nM}$ and $0.38 \mathrm{nM}$ in presence of compounds 12 and $\mathbf{1 3}$ respectively (Figure 4) [34], even better effects than the previous study [33]. Sub-nanomolar range was achieved on CA IX by twelve derivatives, at least one order of magnitude lower than previously reported series [33]. An exceptional result was obtained with $\mathbf{1 4}(\mathrm{Ki}=0.089 \mathrm{nM}$; Figure 4), around two orders of magnitude lower respect 11. Besides, an interesting inhibition of the membrane-bound isoform CA XII, with an $\mathrm{IC}_{50}$ of around $10 \mathrm{nM}$ was gained. In the same work, the author tested the ability of their 1,2,4-oxadiazole derivatives [33,34] to affect the cell culture viability of non-cancerous human retinal pigment epithelial cell line (ARPE-19) in comparison to pancreas ductal adenocarcinoma cell line (PANC-1). The analysis was conducted in presence of $50 \mu \mathrm{M}$ compounds under chemical hypoxic conditions, to closely reproduce the solid tumors environment, turning out seven compounds (included 13 and 14) more effective towards PANC-1 (30\% more cytotoxic) than ARPE-19. Therefore, the most promising compounds were evaluated in normoxic and hypoxic conditions, comparing ARPE-19 with the two cancer cell lines PANC-1 and SK-MEL-2. In particular, 14 displayed selective cytotoxicity to melanoma SK-MEL-2 cells at $30 \mu \mathrm{M}$, while effects on normal cells were observed only at higher concentrations $(100 \mu \mathrm{M})$. Conversely, marked cytotoxicity towards PNA-1 under hypoxic conditions was moved to 15 (Figure 4), which had shown a selective inhibition towards CA cancer-related isoform XII (versus IX) with a Ki value of $8.9 \mathrm{nM}$ [34].

It is interesting to note how the replacement of 1,2,4-oxadiazol-5-yl-thiophene (14) with 1,2,4-oxadiazol-3-yl-thiophene (15) can modulate the specific selectivity versus a particular cell line.

\subsection{Specific Interactions with Histone Deacetylase Isoforms}

Human histone deacetylases (HDACs) are an enzyme family of eighteen species, which is divided into four classes. Their role is to deacetylate Lys residues on a histone, leading to more tightly wrapped DNA with less accessibility toward these transcriptionally active regions [35]. Their action is opposite to histone acetyltransferases, which transferred an acetyl group from acetyl-coenzyme A to Lys amino acids on histone proteins, increasing gene expression. Besides the histone alterations, HDACs can remove acetyl unit also from non-histone proteins, including estrogen receptors, transcription factors, and chaperons. In this sense, it interferes with several DNA processes, such as protein stability and DNA binding activity [36]. Considering that the overexpression or abnormal recruitment of HDACs are the most frequent epigenetic alterations in tumor onset and progression, inhibition of HDACs has been considered a promising strategy to fight cancer spread [37]. Here we reported some examples in which oxadiazole units participate in HDACs' binding, inducing a class-selective and isoform-specific inhibition. 
In general, the pharmacophore model of an HDAC inhibitor is constituted of three different parts: a binder of $\mathrm{Zn}^{2+}$ ion, a linker region to accommodate the $\mathrm{Zn}$-coordinator into the catalytic binding site of HDAC and a cap group used as selective vector. Rajak et al. synthesized hydroxamic acids, containing 2,5-disubstituted 1,3,4-oxadiazole as surface recognition cap group, which resulted in a moderate anticancer activity due to specific HDAC1 inhibition [38]. In particular, 16 (Figure 5) displayed an inhibitory activity against $\mathrm{HDAC} 1\left(\mathrm{IC}_{50}=0.017 \mu \mathrm{M}\right)$ at least equal to positive control Trichostatin $\mathrm{A}\left(\mathrm{IC}_{50}=0.016 \mu \mathrm{M}\right)$ and an $\mathrm{IC}_{50}$ of $0.28 \mu \mathrm{M}$ against human colon cancer cell (HCT-116) proliferation. Moreover, testing its activity in vivo against Ehrlich ascites carcinoma cells in Swiss albino mice, they measured $85.7 \%$ inhibition of Ascitic fluid and 77.7\% of Ascitic cell, using Mitomycin-C as standard [38].
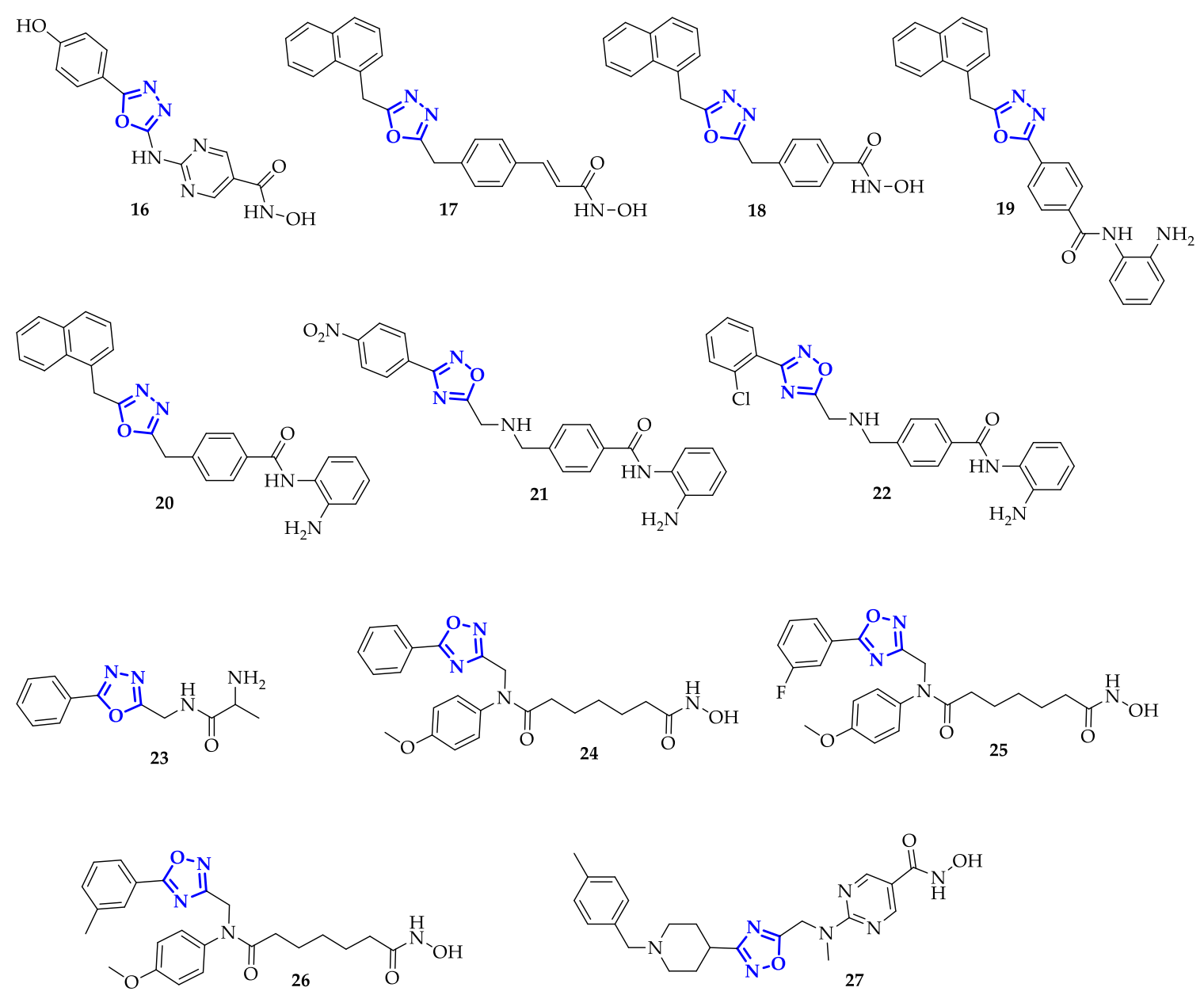

Figure 5. Example of oxadiazoles ligands able to efficiently inhibit histone deacetylases.

Valente et al. exploited 1,3,4-oxadiazole as polar connection linker in the design of a novel series of hydroxamates and 2-aminoanilides. Overall, these derivatives resulted very effective in inhibition of HDAC1, while only 1,3,4-oxadiazole hydroxamates compounds showed good results also against HDAC6 [39]. In particular, hydroxamates 17 and 18 (Figure 5) reached the highest inhibitory potency against $\mathrm{HDAC} 1$ with an $\mathrm{IC}_{50}$ of $0.20 \pm 0.01 \mu \mathrm{M}$, comparable with positive control Vorinostat $\left(\mathrm{IC}_{50}=0.30 \pm 0.02 \mu \mathrm{M}\right)$, the first FDA-approved HDAC inhibitor for $\mathrm{T}$ cell lymphoma progression treatment [40]. Moreover, the presence of cinnamic moiety, instead of benzoic ones, made $\mathbf{1 7}$ around two orders of magnitude more potent in the HDAC6 inhibition $\left(\mathrm{IC}_{50}=0.030 \pm 0.001 \mu \mathrm{M}\right)$ than 18, and twice as high as positive control $(0.060 \pm 0.003 \mu \mathrm{M})$. HDAC1 was successful inhibited also by the 2-aminoanilide derivatives 19 and 20 ( $\mathrm{IC}_{50}$ of $0.30 \pm 0.02 \mu \mathrm{M}$ and $0.20 \pm 0.01 \mu \mathrm{M}$, respectively; Figure 5), which, on the contrary, were not active against HDAC6. These compounds $(5 \mu \mathrm{M})$ 
increased acetyl-histone $\mathrm{H} 3$ levels in human acute monocytic myeloid leukemia cells (U937), as well as acetyl- $\alpha$-tubulin levels, according to their potency on HDAC inhibition. Moreover, they showed an induction of p21, regulator of p53-repression targets [41], greater than Vorinostat in the case of 18 [39]. Besides, 18 and 20 provided a block of U937 cell cycle, similarly to Vorinostat, displaying a dose-dependent apoptotic effect (evaluating pre-G1 peaks). In this sense, 17 revealed the best apoptotic activity in U937 cells: from $58 \%$ at $5 \mu \mathrm{M}$ to $78 \%$ at $25 \mu \mathrm{M}$ ( $5 \mu \mathrm{M}$ of Vorinostat induced $48 \%$ of apoptosis). The granulocytic differentiation in human leukemia U937 cells was also evaluated considering the expression of the surface antigen CD11c as a marker. For all tested compounds, the cytodifferentiation resulted lower than the positive control Entinostat (despite increased in a dose-dependent manner), except for 20 that induced an increase of CD11c expression comparable to control (around 50\% at $5 \mu \mathrm{M}$ after $48 \mathrm{~h}$ ). Moreover, the antiproliferative activities of the best 1,3,4-oxadiazoles derivatives 17 and 20 were comparable, highlighting a more responsive proliferation inhibition in the micromolar range against the colorectal adenocarcinoma SW620 and on all the human acute myeloid leukemia tested cell lines (U937, HL60, HEL, KG1, and MOLM13). Compounds ( $2.5 \mu \mathrm{M})$ were tested also in combination with doxorubicin $(0.2 \mu \mathrm{M})$ in U937 cells and 20 induced cell growth arrest in a major extent than vorinostat/doxorubicin combination [39]. Taken together, these data confirmed the ability of these 1,3,4-oxadiazoles conjugates to trigger apoptosis, cell differentiation, and cell growth arrest processes via HDAC1 selective inhibition.

Following the same example, Cai et al. designed and synthesized hydroxamate and 2aminobenzamide derivatives with 1,2,4-oxadiazole as polar connection linkers [42]. The efficacy of their series was proved against five human cancer cell lines: U937, HCT-116, human breast cell cancer (MDA-MB-231), and human lung cancer cells (A549 and NCI-H661). The MTT-based assay highlighted that only 2-aminobenzamide derivatives manifested a significative antiproliferative activity in comparison with Vorinostat and Entinostat controls, and the most notable results were obtained by compounds with electron-withdrawing group on the benzene unit. Among them, 21 and 22 (Figure 5) reached good antiproliferative activity over all the five cancer cells tested, with $\mathrm{IC}_{50}$ values in the micromolar and sub-micromolar ranges (against U937), comparable with the positive controls. Their antiproliferative activity was directly correlated to their ability in $\mathrm{HDAC} 1$ inhibition $\left(\mathrm{IC}_{50}\right.$ values of $60 \mathrm{nM}$ for 21 and $70 \mathrm{nM}$ for 22) higher than positive controls. They resulted only partially selective: indeed, lower activity was measured towards HDAC2 ( $\mathrm{IC}_{50}$ values of $150 \mathrm{nM}$ and $320 \mathrm{nM}$ for 21 and 22, respectively) and only negligible effects were recorded on HDAC8, slightly inhibited by hydroxamate derivate [42].

Considering that oxadiazole linkers seem to enhance HDAC inhibitory activity, Pidugu et al. developed a series of 2,5-disubstituted-1,3,4-oxadiazoles to selectively interact with HDAC8 [43]. In this work, the best interactions were observed with ligands bearing glycine/alanine residues able to bind $\mathrm{Zn}$ moiety. By in silico analysis, 23 (Figure 5) reached the best dock score with HDAC8 $(-7.918 \mathrm{kcal} / \mathrm{mol})$ showing strong and direct interactions with Tyr306, Gly151, as well as Phe152 binding site residues. Using recombinant purified HDAC8, it was verified the potency and selectivity of 23, which inhibited HDAC8 in vitro with an $\mathrm{IC}_{50}$ of $98.0 \pm 6.0 \mathrm{mM}$, fifteen times lower than Vorinostat $\left(\mathrm{IC}_{50}=1480.0 \pm 5.6 \mathrm{mM}\right)$. Its moderate selectivity was proved by testing the activity of 23 on immunoprecipitated class I HDAC enzymes from MDA-MB-231 cell lysates. 23 (100 nM) selectively inhibited HDAC8 (53\%) liken HDAC1 (30\%), HDAC2 (19\%), and HDAC3 (0\%) [43]. Moreover, the MTT assay proved that 23 was the most active compound $\left(\mathrm{IC}_{50}=230 \mathrm{nM}\right)$ against breast cancer MDA-MB-231 cells, with an antiproliferative potential more than one order of magnitude higher than Vorinostat $\left(\mathrm{IC}_{50}=6000 \mathrm{mM}\right)$. Nevertheless, comparable sub-micromolar results were obtained from all the glycine/alanine derivatives here studied [43].

Based on the inhibition of class I HDAC, and specifically against HDAC1, Yang et al. designed a family of 1,2,4-oxadiazoles containing bi-substituted aromatic amides [44]. In general, all compounds showed good inhibition of HDAC1 (inhibition percentages were above $83 \%$ at $20 \mathrm{nM}$ ) compared to vorinostat (60\%). Among them, three compounds-24, 25, and 26 (Figure 5)—inhibited HDAC1 by 
$90 \%$, showing promising activities with $\mathrm{IC}_{50}$ values in the nanomolar range, slightly lower than the positive control. In this context, 24 appeared to be the most active against $\mathrm{HDAC} 1$ with an $\mathrm{IC}_{50}$ of $8.9 \mathrm{nM}$, two-fold lower than Vorinostat $\left(\mathrm{IC}_{50}=15 \mathrm{nM}\right)$. Testing the antiproliferative activity of these three compounds against human hepatocellular carcinoma cells (HCCLM3 and HepG2) no significant improvements were identified for HCCLM3 cells ( $\mathrm{IC}_{50}$ in the micromolar range), while $\mathbf{2 4}$ and $\mathbf{2 5}$ showed $\mathrm{IC}_{50}$ values of $1.07 \mu \mathrm{M}$ and $1.03 \mu \mathrm{M}$, respectively, against HepG2 cells (fourfold lower than control) [44]. Accordingly, the authors evaluated the acetylation level of histone H3 and H4 in HepG2 cells as a response to HDAC inhibition, confirmed by a marked dose-dependent upregulation, due to ligands presence. In particular, the best results were obtained by 25 for the $\mathrm{H} 3$ acetylation [44].

Synthesis of four different libraries of 1,2,4-oxadiazoles, as cap group, bearing one $\mathrm{N}$-substituted piperidine and connected to a hydroxamate group were proposed by Yang et al. during the same year [45]. They tested the inhibition potency towards HDAC1 and HDAC6, evidencing a major efficiency in HDAC6 downregulation ( $>58 \%$ ) for their first compounds' family and higher HDAC1 inhibition for the fourth compounds' family $(>62 \%)$. In this series, compound 27 (Figure 5 ) showed the best selective HDAC1 inhibition of 96\% (inhibition of HDAC6 of 71\%). Antiproliferative activity of 27 towards Raji cell line was so outstanding $\left(\mathrm{IC}_{50}=12.1 \pm 1.9 \mathrm{nM}\right)$ that the compound was also evaluated towards other HDAC isoforms (1-11), arising effective against class I HDAC1, 2, and 3 with $\mathrm{IC}_{50}$ values in the nanomolar range ( $\mathrm{IC}_{50}$ of $1.8,3.6$, and $3.0 \mathrm{nM}$, respectively), one order of magnitude lower than vorinostat. Therefore, in vitro antiproliferative activity of 27 was estimated towards 12 tumor cell lines, including solid and hematological tumors, and three primary AML cell lines. $\mathrm{IC}_{50}$ values ranged from 9.8 to $44.9 \mathrm{nM}$, a very promising result considering that the lower $\mathrm{IC}_{50}$ value obtained with Vorinostat was above $500 \mathrm{nM}$ [45]. Acetylations of histone $\mathrm{H} 3$ and $\alpha$-tubulin in the MM1S cells were upregulated by $\mathbf{2 7}$ in a dose-dependent manner, and, at low $\mathbf{2 7}$ concentrations, the relative expression was higher than vorinostat treatment. Moreover, 27 induced G1 cell cycle arrest in Jeko-1 cells with $73.1 \%$ of cell apoptosis after $48 \mathrm{~h}$ at $1 \mu \mathrm{M}$ compound. These results highlighted that 27 is a promising 1,2,4-oxadiazole derivative, acting as a potent anticancer agent. Therefore, after checking its excellent bioavailability in SD rats, the antitumor potency of $\mathbf{2 7}$ was determined on a Burkitt's lymphoma Daudi xenograft model. The compound was able to reduce tumor growth by around $50 \%$, increasing the expression of acetylated histone $\mathrm{H} 4$ in tumor tissue and leading to reduced tumor proliferation and increasing DNA damage of tumor cells [45].

\subsection{Efficient Kinases Inhibitors}

Human kinases are enzymes whose role is to transfer one $\gamma$-phosphate group from ATP to a specific substrate. The phosphorylation of a biological entity can affect its activity, then, for this reason, kinases are involved in many cellular pathways essential to human physiology, including protein regulation, cell signaling and metabolism. The direct consequence is their association with the human cancer initiation and progression, making these enzymes one of the most important pharmaceutical targets in clinical cancer therapy [46]. In this context, the most recent oxadiazoles derivatives were designed and studied as inhibitors of focal adhesion kinase (FAK) [47], phosphoinositide 3-kinases (PI3Ks) [48] and different receptor tyrosine kinases [49-51].

Zhang et al. identified an efficient FAK inhibitor, 28 (Figure 6), testing a family of compounds whose chemical structures were based on 1,3,4-oxadiazoles conjugated to benzotriazole unit [47]. They evaluated their anticancer activity against MCF-7 and HT29 cell lines using Cisplatin as a reference drug. Compound 28 showed the best antiproliferative activity against MCF-7 cells $\left(\mathrm{IC}_{50}=5.68 \mu \mathrm{g} / \mathrm{mL}\right)$, twice as higher as positive control $\left(\mathrm{IC}_{50}=11.20 \mu \mathrm{g} / \mathrm{mL}\right)$, and moderate activity against HT29 cells $\left(\mathrm{IC}_{50}=10.21 \mu \mathrm{g} / \mathrm{mL}\right)$, slightly lower than Cisplatin $\left(\mathrm{IC}_{50}=15.83 \mu \mathrm{g} / \mathrm{mL}\right)$ [47]. Despite most of the designed compounds displayed high FAK inhibitory potency, only 28 resulted to be eightfold more effective than Cisplatin ( $\mathrm{IC}_{50}$ of $1.2 \pm 0.3 \mu \mathrm{M}$ liken $8.6 \pm 0.2 \mu \mathrm{M}$ ). Moreover, its apoptotic effect on activated MCF-7 cells resulted to be dose-dependent, reaching $61.29 \%$ on MCF-7 cells with $20 \mu \mathrm{g} / \mathrm{mL}$ of 28 for $24 \mathrm{~h}$. These promising results were in perfect accordance with the predicted interactions 
between 28 and the active binding site of FAK (PDB code: 2ETM). The nitrogen atom of oxadiazole moiety instituted a hydrogen bond with Cys502, while the benzene ring formed a $\pi$-cation interaction with Lys454 [47].<smiles></smiles>

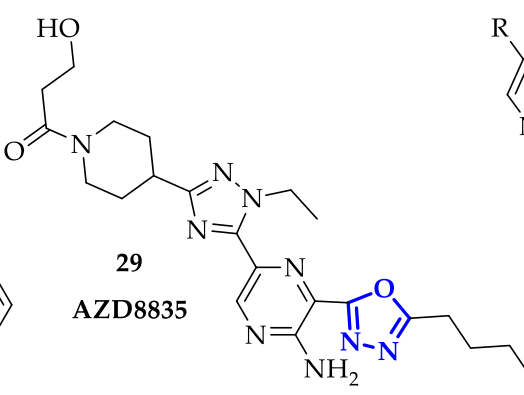

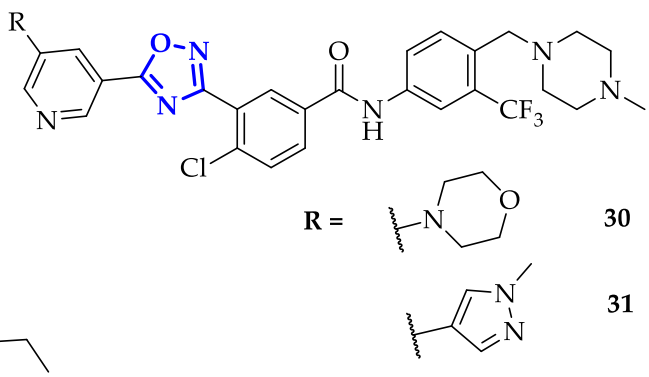<smiles>Nc1ccccc1-c1nnc(SCc2ccccc2)o1</smiles><smiles>COc1cc(-c2nnc(-c3ccc(-c4noc(-c5cccc([N+](=O)[O-])c5)n4)cc3)o2)cc(OC)c1OC</smiles>

Figure 6. Oxadiazoles ligands that exploited kinases inhibition to reach an anticancer activity.

Another interesting kinase target is a group of lipid kinases, PI3Ks, whose biological activity resulted in protein kinase B (AKT) recruitment inducing a cascade of cell signaling. Barlaam et al. optimized kinase-specific selectivity of a potent PI3Ks inhibitor developing a family of twenty-five 1,3,4-oxadiazoles derivatives [48]. Among them, the authors revealed the outstanding compound 29, known as AZD8835 (Figure 6), able to inhibit cancer progression by blocking the PI3K pathway components PI $3 K \alpha$ and $\beta$. It reached the phase I clinical trials sponsored by AstraZeneca (www. ClinicalTrials.gov Identifier: NCT02260661) to evaluate its safety and pharmacokinetics in patients with advanced solid tumors. Compounds 29 displayed superior potency and selectivity toward PI3K $\alpha$ $\left(\mathrm{IC}_{50}=10 \mathrm{nM}\right)$ with good metabolic stability. A competitive selectivity was confirmed only with BMPR1B enzyme ( $K_{d}$ value of $12 \mathrm{nM}$ versus $2.3 \mathrm{nM}$ for wild type PI3K $\alpha$ ) and PI4K $\alpha$ and PI4K $\beta$ (more than 50 -fold selectivity margin versus PI3K $\alpha$ ) outside PI3K class I enzymes. Moreover, 29 resulted to be able to specifically interact also with mutated PI3K $\alpha$ enzymes (E542K, E545K, H1047R) aside from wild type PI3K $\alpha$, with the same range of $K_{d}$ values [48]. The potency of 29 in enzyme inhibition was common for all class I PI3K enzymes: $\mathrm{IC}_{50}$ values in the nanomolar range for PI3K $\delta$ and PI3K $\alpha$ (wild type and mutated), one order of magnitude higher against PI3K $\gamma$ and two order against PI3K $\beta$. In cell-based assay, testing the ability in AKT phosphorylation inhibition, it has been discovered that 29 affected cells sensitive to PI3K $\alpha\left(\mathrm{IC}_{50}=0.057 \mu \mathrm{M}\right.$ in BT474 cells) and PI3K $\delta\left(\mathrm{IC}_{50}=0.049 \mu \mathrm{M}\right.$ in Jeko-1 B cells). Because of its good solubility and permeability, as well as low turnover in hepatocytes, the effects of $\mathbf{2 9}$ on AKT phosphorylation (at Ser473 residue) were followed in nude mice bearing mutant H1047R PI3K $\alpha$ SKOV-3 tumor xenografts. Significant inhibition was only seen at $25 \mathrm{mg} / \mathrm{kg}$ dose, in accordance with the lower plasma concentrations after $8 \mathrm{~h}$ from the administration. Anyhow, in the same model, almost complete inhibition of tumor growth (93\%) was measured after chronic oral administration [48]. 
Taking into account that oncogenic mutations can activate RET receptor tyrosinase kinase leading to its direct involvement in different carcinomas, RET inhibition may represent a promising goal for anticancer therapy. Han et al. have developed five different compounds containing 1,2,4- and 1,3,4-oxadiazoles units to increase the RET inhibitory potency of the previously synthesized Hu1-117 $\left(\mathrm{IC}_{50}=2.5 \pm 0.2 \mathrm{nM}\right)$ [49]. Despite the presence of 1,2,4-oxadiazoles led to higher RET enzymatic activities than corresponding 1,3,4 regioisomers (at least one order of magnitude higher), none showed an $\mathrm{IC}_{50}$ lower than Hu1-117 (in which oxadiazole unit is replaced with an alkynyl spacer). Maintaining the 1,2,4-oxadiazole moiety, the authors designed and synthesized new compounds containing different phenyl and pyridine rings. $\mathbf{3 0}$ and $\mathbf{3 1}$ (Figure 6) reached good RET inhibitory activity $\left(\mathrm{IC}_{50}=2.1 \pm 0.1 \mathrm{nM}\right.$ and $\mathrm{IC}_{50}=1.80 \pm 0.01 \mathrm{nM}$, respectively) more efficiently than Hu1-117 and in particular, $\mathrm{IC}_{50}$ value obtained for 31 resulted only twofold higher than positive control Ponatinib $\left(\mathrm{IC}_{50}=0.9 \pm 0.2 \mathrm{nM}\right) .31$ efficiently block the RET signaling pathways in BaF3/CCDC6-RET cells, indeed, at $1 \mu \mathrm{M}$ concentration it completely abolished phosphorylation of RET and of two RET-key downstream molecules (STAT3 and ERK) [49]. Moreover, 31 inhibited cell proliferation with a similar potency for BaF3/CCDC6-RET cells and gatekeeper mutant V804 M-driven cell proliferation ( $\mathrm{IC}_{50}$ value around $400 \mathrm{nM}$ ) highlighting that it could be active against both these RET-driven cancer cells. These results corresponded to the binding mode of $\mathbf{3 1}$ on RET active sites (RET ${ }^{\mathrm{WT} / \mathrm{V} 804 \mathrm{M}}$ DFG-out homology model). Oxygen and nitrogen atoms of 1,2,4-oxadiazole are involved in H-bond interaction with Asp892, while fluorine atom with Ala807. At the same time, oxadiazole orientates the 3-substituted position leading to the formation of $\pi$-cation interaction between phenyl ring and Lys758, and a $\pi-\sigma$ interaction between phenyl ring trifluoromethyl-substituted and Phe893 [49].

Another family of receptors tyrosine kinases is represented by Epidermal Growth Factor Receptor (EGFR), a transmembrane protein tyrosine kinase activated by ligand-induced dimerization and involved in key processes such as cell proliferation, differentiation, and migration [52]. EGFR overexpression has been associated with the spread of a broad variety of tumors, including lung, ovarian, breast, prostate, and kidney [53]. Therefore, it is not surprising that several small molecules found application as EGFR inhibitors in antitumor context. Liu et al., decided to investigate the biological activity of a library of 2-(benzylthio)-5-aryloxadiazoles, differing for the substituents introduced on aryl moiety in position 5 [50]. Cytotoxicity against MCF-7, A459 and B16-F10 has been measured and compound 32 (Figure 6), characterized by the presence of a free amino group on phenyl ring, emerged as the most toxic substrate with an $\mathrm{IC}_{50}$ value of $1.09 \mu \mathrm{M}$ on MCF-7 cells. The same compound showed also a pronounced inhibitory effect on EGFR $\left(\mathrm{IC}_{50}=1.51 \mu \mathrm{M}\right)$, coherent with the result of the antiproliferative activity test. Docking studies confirmed favorable interactions of 32 with ATP-binding pocket of EGFR, indicating the potential of identified oxadiazole scaffold as anticancer drug.

Polothi et al. suggested to combine two oxadiazole units (1,2,4- and 1,3,4-) to enhance their anticancer activity. They synthesized various molecules, differing for the type of substituents introduced on one phenyl ring, and tested these compounds towards MCF-7, A549, and MDA-MB-231 cells [54]. In general, $\mathrm{IC}_{50}$ values resulted to be particularly low (below $10 \mu \mathrm{M}$ ), especially on A459 cells. However, the most toxic compound was 33 (Figure 6), which displayed an $\mathrm{IC}_{50}$ value of $0.34 \pm 0.025 \mu \mathrm{M}$ on MCF-7 cells. Docking studies confirmed that 33 was potentially able to ensure strong interaction with the binding site of EGFR [54].

In combination with EGFR inhibitors development, very recently Dokla et al. found a new 1,2,4-oxadiazole derivative able to efficiently downregulate also hepatocyte growth factor receptor (c-Met), directly involved in tumors growth and progression [51]. The presence of urea as a linker between phenyl-oxadiazole and a second phenyl ring, followed by trifluoromethyl and cyclopropylamyde substitution, allowed the design of 34 (Figure 6), which presented a broad spectrum of antiproliferative activity with an $\mathrm{IC}_{50}$ lower than $1 \mu \mathrm{M}$. Once clarified the ability of $\mathbf{3 4}$ in suppressing EGRF and c-Met expression, five non-small cell lung cancer cell lines with different EGRF mutational status were used to elucidate the antitumor mechanism of $\mathbf{3 4}$. Compound $\mathbf{3 4}$ showed consistent 
antiproliferative efficacies against the five tested cell lines, with $\mathrm{IC}_{50}$ values in the range of 0.2 to $0.6 \mu \mathrm{M}$. Its ability in EGFR and c-Met expression downregulation was confirmed by Western blot analysis $\left(\mathrm{IC}_{50}\right.$ values in the range of 0.2 to $0.6 \mu \mathrm{M}$ ) occurring with a decrease in AKT phosphorylation (apart from CL68 cells). Moreover, RT-PCR demonstrated that mRNA levels of EGFR and c-Met were maintained unaltered in H1975 and A549 cells, suggesting a drug effect at protein levels [51]. Guided by the good results, the authors tested the tumor-suppressive action of $\mathbf{3 4}$ in athymic nude mice bearing subcutaneous H1975 xenograft tumors. Compound 34 disclosed a dose-dependent suppression of xenograft tumor growth until $60 \%$ at the end of 20-day treatment with $150 \mathrm{mg} / \mathrm{Kg}$ oral administration. No acute toxicities were associated with its administration and it has been demonstrated that tumor suppression was directly correlated with EGFR and c-Met expression [51].

\subsection{Other Targeted Enzymes}

In addition to the previously reported studies, Ozcan et al. designed and studied a highly selective and potent inhibitor of chymotrypsin-like (CT-L) activity to impact on catalytic processes of the proteasome [55]. Starting from the identification of 35 (Figure 7) with an $\mathrm{IC}_{50}$ value of $0.60 \mu \mathrm{M}$, the authors analyzed the structure-activity relationship of novel 58 compounds reaching the most promising structure 36 (Figure 7). This 1,2,4-oxadiazole derivative showed an $\mathrm{IC}_{50}$ value of $0.027 \pm 0.014 \mu \mathrm{M}$ as an average of 20 determinations, 22-fold lower than 35 , with an excellent selectivity for CT-L inhibitions over both T-L and PGPH-L activities $\left(\mathrm{IC}_{50}>100\right)$.

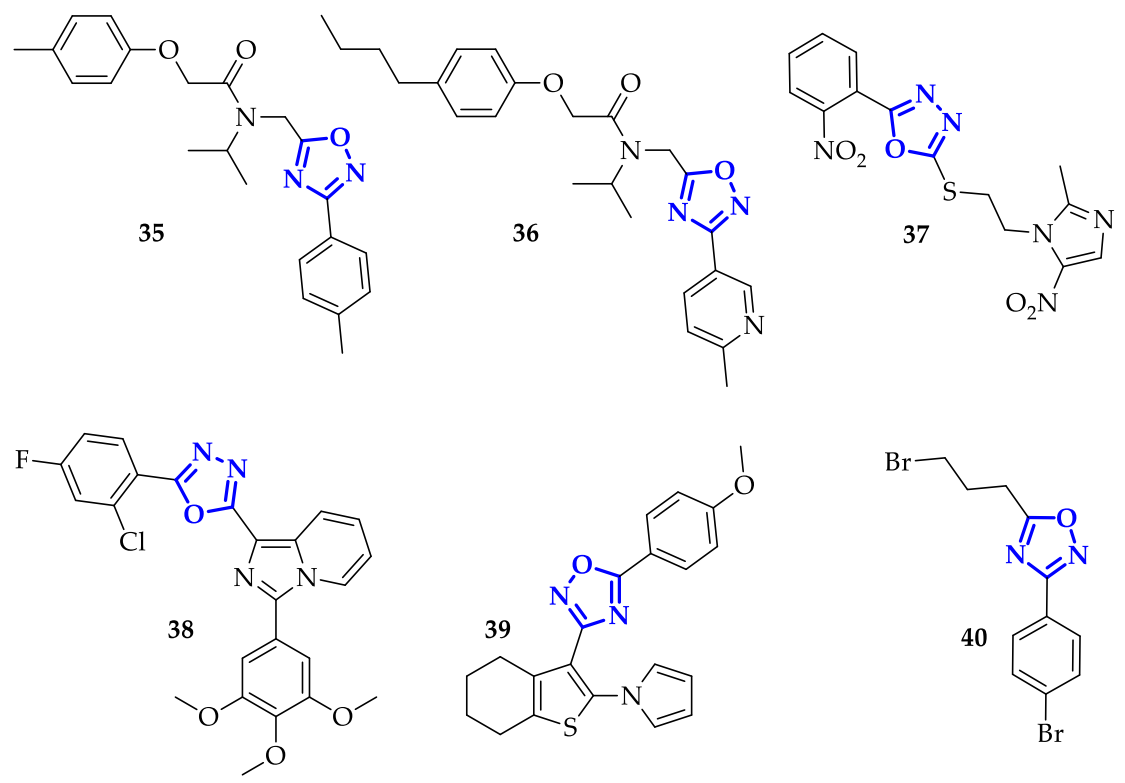

Figure 7. Chemical structures of oxadiazole scaffolds involved in different enzyme binding.

Thymidylate synthase (TS) is recognized as another attractive target in chemotherapy for its role in DNA biosynthesis. Indeed, its inhibition can lead to deoxynucleotide imbalances. The most famous antitumor agent that acts through irreversible inhibition of TS is 5-fluorouracil [56]; nonetheless, the progressive resistance to this drug of several tumors has triggered the design of new molecules. Although different successful works have been developed in this field, Du et al. proposed a series of novel 1,3,4-oxadiazole thioether derivatives, among which 37 (Figure 7) exhibited outstanding anticancer activities in vitro [57]. The authors firstly tested the anticancer activities of 1,3,4-oxadiazoles family against HepG2, SGC-7901, and MCF-7 cancer cells, highlighting the higher potency of 37 liken 5-Fluorouracil on all the cell panel, and a twofold higher $\mathrm{IC}_{50}$ against $\mathrm{HepG} 2\left(\mathrm{IC}_{50}=0.7 \pm 0.2 \mu \mathrm{M}\right)$ compared to Raltitrexed ( $\left.\mathrm{IC}_{50}=1.3 \pm 0.2 \mu \mathrm{M}\right)$, both used as positive controls. Specifically, 37 appeared to be a potent inhibitor of human TS $\left(\mathrm{IC}_{50}=0.62 \mu \mathrm{M}\right)$ resulting 15 -fold more potent than Pemetrexed $\left(\mathrm{IC}_{50}=9.5 \mu \mathrm{M}\right)$ and twofold less active than Raltitrexed $\left(\mathrm{IC}_{50}=0.38 \mu \mathrm{M}\right)$. 
Another important enzyme involved in DNA biology is DNA Topoisomerase II (topo II), which controls DNA structure by catalyzing DNA cleavage and phosphodiester bonds degradation. Recently, topo II inhibitors became clinically useful as chemotherapeutical agents, and in this slice Rao et al. have developed imidazopyridinyl-1,3,4-oxadiazole conjugates, among which 38 (Figure 7) was able to affect the catalytic activity of this specific enzyme [58]. In particular, it exhibited a great growth cell inhibition in a panel of sixty cancer cell lines (mean growth of $33.54 \%$ ) among which the most sensitive cell line was a non-small cell lung cancer (HOP-62). Its molar concentration required to cause $50 \%$ growth inhibition ( $\mathrm{GI}_{50}$ ) were in the range of 1.30 to $5.64 \mu \mathrm{M}$, exhibited a broad spectrum of cytotoxicity. Subsequently, the authors verified the ability of 38 in causing cell cycle arrest at sub G1 phase till $41.70 \%$, as well as reduction of cell population in G1 phase. Once its induced apoptotic activity was identified, increasing in intracellular ROS production was also verified, suggesting that cytotoxicity and apoptosis caused by $\mathbf{3 8}$ probably resulted from the mitochondrial pathway [58].

Conjugation of 1,2,4-oxadiazoles to thiophene, performed by Mohammed et al., led to significant toxicity on MCF-7 and HTC-116, with the identification of potent antiproliferative agent 39 (Figure 7) [59], characterized by $\mathrm{IC}_{50}$ value of $0.19 \pm 0.05 \mu \mathrm{M}$ on MCF-7 cells. This compound strongly inhibited topo II and, as confirmed by flow cytometry analysis, induced cell cycle arrest at G1 phase. Its proapoptotic behavior was further demonstrated by increased levels of p53 protein and other cell death modulators (Puma, Bax, and Bcl-2), measured through Western blot analysis [59].

Oxadiazoles showed marked biological effects also with the class Sirtuin (Sirt), a family of $\mathrm{NAD}^{+}$-dependent lysine deacetylases that share a conserved $\mathrm{NAD}^{+}$-binding and catalytic core domain [60], and are involved in critical physiological processes as regulation of transcription, genome stability and cell survival [61]. Despite the role of these enzymes is not completely clear, several Sirt-inhibitors found application as anticancer agents. A previous work of Moniot et al. evidenced specific binding interactions between Sirt2 and 3-(4-chlorophenyl)-5-(piperidin-1-ylmethyl)-1,2,4-oxadiazole, unfortunately combined with poor solubility and low bioavailability [62]. To identify novel potential bioactive compounds, they examined how modifications of the aromatic scaffold, replacement of piperidine with other amines and spacer length can affect the specificity towards Sirt2 [63]. The authors performed a preliminary screening to individuate the most potent inhibitors of the library: the percentage of residual activity of Sirt 2 has been measured after the treatment with 10 and $100 \mu \mathrm{M}$ of oxadiazoles. Compound 40 (Figure 7) was the best inhibitor, with a percentage of residual activity below 25\% at $10 \mu \mathrm{M}$. Subsequently, the selectivity of $\mathbf{4 0}$ for Sirt2 has been assessed in presence of other Sirt2 isoforms, as well as was determined its ability in protein activity inhibition in presence of the substrate. Cytotoxicity of $\mathbf{4 0}$ was measured against a panel of cancer cell lines, including U937, NB4, HL-60, K562, and MDA-MB-231, showing a particularly high toxicity against NB4 cells at $10 \mu \mathrm{M}$ and inducing apoptosis, above $80 \%$, in U937 cells at $50 \mu \mathrm{M}$. To confirm that the observed biological activity was related to Sirt2 inhibition, NB4 and U937 cells were treated with $40(5$ and $25 \mu \mathrm{M})$ for 4 and $24 \mathrm{~h}$, monitoring the levels of acetyl- $\alpha$-tubulin. In both cases, a significant increase of acetylated tubulin has been observed, confirming the selective mechanism of action of $\mathbf{4 0}$ as an antitumor agent [63].

\section{Specific Interaction with Globular Proteins: Tubulin-Binding Drugs}

The constant effort dedicated to cancer research led to the identification of novel and effectiveness targets, extremely useful in the development of groundbreaking therapeutical strategies. In particular, it has been demonstrated that inhibition of several proteins could interfere with the progress of the disease. Among them, tubulin emerged as one of the most promising targets [64]. It is a filamentous protein that generates microtubules upon dimerization, which are responsible for critical cellular functions as intracellular transport, shape of cells, mitosis, polarity of cells, cell signaling, cellular integrity, and gene expression [65]. Suppression of tubulin polymerization causes an arrest of cell cycle in metaphase-anaphase transition and, subsequently, induces apoptotic cell death [66]. Therefore, tubulin inhibition has been widely exploited as a promising anticancer strategy. Several small molecules have been used for this purpose; as famous alkaloid derivatives, such as vincristine and 
vinblastine [67]; as well as different classes of organic compounds, including quinazolones [68], benzimidazoles [69], benzothiazoles [70], and triazoles [71]. In this context, oxadiazoles emerged as an alternative tubulin inhibitor.

Nieddu et al. [72] synthesized different 1,3,4-oxadiazoles bearing dihydroindenopyrrole moiety in position 2, evidencing the relevance of the extension of the aromatic core for antitumor properties. They found that 41 (Figure 8) presented the highest toxicity on HeLa $\left(\mathrm{IC}_{50}=0.05 \mu \mathrm{M}\right)$ and MCF-7 $\left(\mathrm{IC}_{50}=1.7 \mu \mathrm{M}\right)$ cells, significantly increasing the percentage of cells in $\mathrm{G} 2 / \mathrm{M}$ phase on A459, MCF-7, PC3 and SH-SY5Y cells. To assess if the observed outcomes are the results of the interaction of $\mathbf{4 1}$ with Tubulin, immunofluorescence analysis has been performed. Incorrect $\beta$-tubulin organization and two nuclei formation derived from $24 \mathrm{~h}$ incubation of $\mathbf{4 1}$ in HeLa cells, while inhomogeneous distribution of $\beta$-tubulin around nuclei, micronucleated cells, and decreasing in nuclei sizes were observed in MCF-7 cells. These results were in perfect accordance with the Tubulin inhibitor activity of $\mathbf{4 1}$ in response to its anticancer potency.

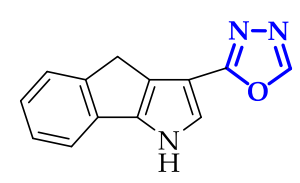

41

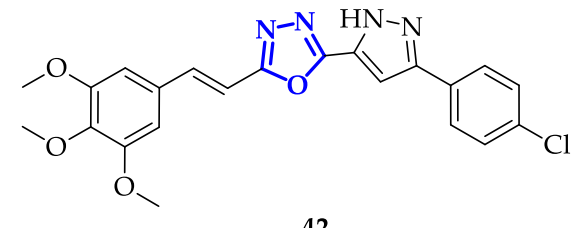

42

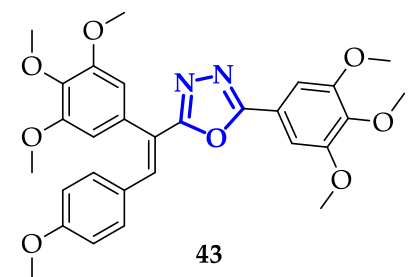

1

Figure 8. Oxadiazoles as tubulin inhibitors.

In an attempt to further improve anticancer activity of 1,3,4-oxadiazoles, Kamal et al. synthesized two series of conjugates pyrazole-oxadiazole: the first one was characterized by trimethoxy-phenyl in position 2, that was subsequently replaced, in the second series, by 3,4-(methylenedioxy)phenyl moiety [73]. As preliminary screening, the authors examined the antiproliferative activity of each derivative towards HeLa, A549, MCF-7, and IMR32 cell lines. In general, the first series of compounds showed higher cytotoxicity and, among them, 42 (Figure 8 ) evidenced IC $_{50}$ values of $1.8 \mu \mathrm{M}$ in MCF-7, $2.3 \mu \mathrm{M}$ in HeLa, and $3.2 \mu \mathrm{M}$ in IMR32 cells. To test its ability in inducing cycle cell arrest in G2/M phase, levels of cyclin-B1 have been analyzed after the treatment of A459 cells with $5 \mu \mathrm{M}$ of compound for $24 \mathrm{~h}$. Interestingly, $\mathbf{4 2}$ showed a marked increase in cyclin-B1 levels, detected through dot blot analysis. Then, the authors incubated cells with different concentrations of $\mathbf{4 2}$ to determine their influence on Tubulin polymerization, recording an $\mathrm{IC}_{50}$ value of $1.3 \mu \mathrm{M}$. Compound 42 significantly increased the number of cells in G2/M phase and, specifically, the treatment on A459 cells resulted in a round morphology of cells, typical of metaphase arrest, suggesting that anticancer activity of $\mathbf{4 2}$ could be mainly attributed to Tubulin inhibition.

The same authors described an alternative strategy aimed to improve the anticancer activity of 1,3,4-oxadiazoles, which relies on the conjugation of these scaffolds with the double bond of Cambrestatin-A4 [74]. Different compounds were screened on HeLa, A549, MDA-MB-231 and mouse macrophage cell line B-16. Compound 43 (Figure 8), characterized by a 3,4,5-trimethoxy substituent, showed the highest efficiency with an $\mathrm{IC}_{50}$ value of $0.118 \mu \mathrm{M}$. From structure-activity relationship (SAR) analysis, it emerged that the presence of electron-donating groups on phenyl ring, conjugated to the oxadiazole, increases the toxicity. To elucidate its mechanism of action, $\mathbf{4 3}$ has been tested in prostate cancer cells (DU-45) to verify its effect on cell cycle. Cells were incubated with $0.5 \mu \mathrm{M} 43$ for $24 \mathrm{~h}$ and arrest at G2/M phase was observed, suggesting that 43 acts as an inhibitor of tubulin polymerization. Inhibition of polymerization has been also observed in vitro, through fluorescent analysis, evidencing 53.6\% of aggregation reduction. Furthermore, incubation of DU-145 cells with 43 caused disrupted microtubule organization with spherical morphology, in direct correlation with inhibition of Tubulin polymerization. 


\section{Nucleic Acid Structures as Oxadiazole Targets}

In clinical use, many anticancer drugs directly interact with DNA. Since the 1960s, the interest in the development of this particular type of anticancer agents increased. Specifically, have been developed compounds that directly modify DNA bases, or interact through base intercalation, or, again, induce crosslinks damage. Considering their high specificity, the further discovery and characterization of such compounds is of considerable interest, therefore DNA-targeted anticancer drugs continue to be strengthened. In this context, different DNA interactive ligands bearing oxadiazole rings have been developed.

Terenzi et al. taking inspiration from platinum-based chemotherapeutic compounds, synthesized two new oxadiazole metal complexes, 44 and 45 (Figure 9), able to bind DNA both by metal coordination and through intercalation of the aromatic fragments [75]. The presence of a positive charge on the metal complex enhanced the electrostatic interactions between ligands and targets, while the labile ligand with counterion can be easily substituted by a nitrogen heterocyclic atom of a DNA base forming a covalent binding. The preliminary biophysical analysis confirmed the interaction with calf thymus DNA: both zinc and copper metal complexes (44 and 45) determined the increase of the DNA melting temperature, the perturbation of DNA circular dichroism signal and good values of intrinsic binding constants, equal to $(6.7 \pm 0.5) \times 10^{6} \mathrm{M}^{-1}$ and $(4.7 \pm 0.5) \times 10^{5} \mathrm{M}^{-1}$ respectively. These complexes were not able to cross the cellular membrane, so biological tests were performed using a lipid carrier (Lipofectamine 2000) for internalization. The analysis led on MDA-MB231 cell line showed a good activity especially for 45 with an $\mathrm{IC}_{50}$ value of $100 \mu \mathrm{M}$. Compound 45 reduced the cell survival in a dose-dependent manner and significantly perturbed their cell cycle profile [75].

The same research group designed and developed different 1,2,4-oxadiazoles metal complexes to improve anticancer activity, exploiting an alternative DNA binding interaction. Among them, Terenzi et al. developed a new copper(II) complex with 3,5-bis(2'-pyridyl)-1,2,4-oxadiazole, compound 46 (Figure 9), to study its interaction mode with DNA and its biological activity against HepG2 and HT29 tumor cells [76]. From circular dichroism analysis and UV melting assays, 46 resulted to be comparable to typical DNA groove binders in terms of binding constant $\left(K_{\mathrm{b}}=2.2 \times 10^{4} \mathrm{M}^{-1}\right)$, DNA melting temperature $\left(\Delta \mathrm{T}_{\mathrm{m}}=6.8^{\circ} \mathrm{C}\right)$ and size of the cationic copper complex. Moreover, these spectroscopic and hydrodynamic investigations showed that while the ligand did not interact with native DNA, the copper(II) complex has the characteristics of a DNA groove binder, displaying good affinity and preserving the native B-DNA form. Biological assays demonstrated that although free ligand 47 (Figure 9) was not effective, the copper complex $\mathbf{4 6}$ showed similar activity on both cell lines, reducing the cellular viability of HepG2 and HT29 in a dose- and time-dependent manner ( $\mathrm{IC}_{50}$ around $5 \mu \mathrm{M}$ at $48 \mathrm{~h}$ ). Moreover, cell morphology and flow cytometric analysis evidenced that the copper complex 46 caused DNA fragmentation in a significant extent amount of cells, confined in the G0/G1 phase of the cell cycle, index of apoptosis [76].

In contrast with metal complexes, Savariz et al. developed new entities based on $\beta$-carboline, well-known for its anticancer properties due to DNA intercalation [77], DNA binding, and DNA synthesis inhibition [78]. In a previous work, the authors improved the antitumor activity of $\beta$-carboline by introducing a thioxo-1,3,4-oxadiazolyl unit at C-3 position of carboline [79]. In an effort to achieve even better effects, they decided to replace the thioxo group with a 2-oxo derivative [80]. Antiproliferative activity was tested towards different cancer cell lines and the best outcome was achieved with 48 (Figure 9), characterized by the presence of N,N-dimethylamino group on carboline. This molecule showed particularly high toxicity on ovarian cancer cell line NCI-ADR/RES, with $\mathrm{GI}_{50}$ of $1.68 \mu \mathrm{M}$. Because of its interesting biological effect, 48 was selected to clarify its interaction with DNA, through fluorescence quenching analysis and competition assay with ethidium bromide. Potassium iodide (KI) was employed in fluorescence quenching assay to measure the occurrence of the quenching process in presence of ctDNA. Therefore, the authors measured Stern-Volmer constant $\left(\mathrm{K}_{\mathrm{SV}}\right)$ values for the free and the bound 48 with ctDNA $(10 \mu \mathrm{M})$, which resulted to be $15.5 \pm 1.4 \mathrm{~L} / \mathrm{mol}$ and $7.15 \pm 0.42 \mathrm{~L} / \mathrm{mol}$, respectively. Lower $\mathrm{K}_{\mathrm{SV}}$ values recorded in presence of ctDNA compared to free 
molecule confirmed the ability of 48 in ctDNA interaction. Furthermore, increasing concentrations of 48 induced reduction of the emission intensity of the EB-ctDNA complex until $62 \%$ (at $20 \mu \mathrm{M}$ 48 ), evidencing that the two ligands (48 and EB) interact with ctDNA in the same mode through intercalation [80].<smiles>CCCNCc1ccccc1-c1nnc(-c2ccccc2CNCCNCCNCC)o1</smiles><smiles>CCCNCc1ccccc1-c1nnc(-c2ccccc2CNCCNCCNCC)o1</smiles>

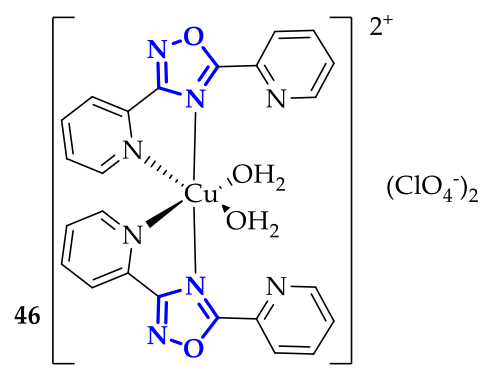<smiles>c1ccc(-c2noc(-c3ccccn3)n2)nc1</smiles><smiles>CN(C)c1ccc(-c2nc(-c3n[nH]c(=O)o3)cc3c2[nH]c2ccccc23)cc1</smiles><smiles></smiles>

$\mathrm{R}=\left(\mathrm{CH}_{2}\right)_{2} \mathrm{NH}\left(\mathrm{CH}_{3}\right)_{2}{ }^{+} \mathrm{Cl}^{-} 49$ $\left(\mathrm{CH}_{2}\right)_{3} \mathrm{NH}\left(\mathrm{CH}_{3}\right)_{2}{ }^{+} \mathrm{Cl}^{-} 50$ $\left(\mathrm{H}_{2} \mathrm{C}\right)_{2} \mathrm{HN} 51$

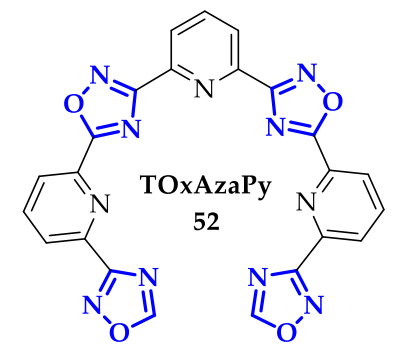

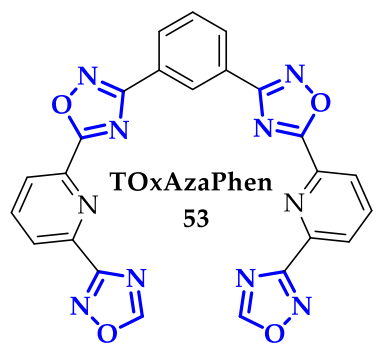<smiles>O=C1C(=C2c3cccnc3-c3ncccc32)SC(=S)N1Cc1nnc(-c2ccc(Br)cc2)o1</smiles>

Figure 9. Nucleic acid ligands containing oxadiazole moieties.

B-DNA is not the only target of oxadiazole anticancer agents, other nucleic acid secondary structures, such as DNA G-Quadruplexes (G4), offer the possibility to control key biological processes in cells. In this context, Freccero's group published, in 2012, the synthesis and the biophysical studies of a family of polyheterocyclic 1,2,4-oxadiazoles ligands (BOxAzaPys, Figure 9) [81]. These ligands, mimicking the well-known macrocyclic G4 binder telomestatin [82], were able to selectively interact and stabilize telomeric G4, inhibiting the activity of telomerase. This new family of acyclic G4 ligands was characterized by excellent water solubility and an unexpected potential. Indeed, BOxAzaPys 49, 50, and $\mathbf{5 1}$ showed excellent G4 selectivity over B-DNA. Using FRET melting assay, 49, 50, and $\mathbf{5 1}$ appeared as good binders of telomeric DNA (F21T in $\mathrm{K}^{+}$buffer) showing $\Delta \mathrm{Tm}$ values of $15.5,10.5$, and $16^{\circ} \mathrm{C}$, respectively, at $1 \mu \mathrm{M}$ of ligand concentration in a large excess of B-DNA as a competitor. G4-FID and circular dichroism assays revealed that their on/off G4 binding properties were clearly controlled by their innovative structural features: the conformational flexibility and the highly hydrophobic character of the pentameric core [81].

These promising results prompted the same researchers to perform a structural tuning of BOxAzaPy ligands to enhance G4 binding. In order to achieve this goal, they decided to modulate the nature and number of the heterocycles linked to the pyridyl oxadiazole central core. Among them, more extended heptacycle-oxadiazole ligands, such as TOxAzaPy and TOxAzaPhen (52 and 53 
in Figure 9) shown high stabilization ability and a preferential binding towards the antiparallel G4 sequence 22AG ( $\Delta \mathrm{Tm}$ values ranging from 13.8 to $16.8^{\circ} \mathrm{C}, 1 \mu \mathrm{M}$ ligand concentrations in $\mathrm{Na}^{+}$buffer) with a remarkable selectivity versus a large excess of duplex DNA [83]. These new heptapyridil-oxadiazoles seem to be more effective and selective than TOxaPy, the benchmark heptacycle G4 ligand. The replacement of 1,3-oxazoles by the 1,2,4-oxadiazole moiety positively affected their binding affinity and led to the unexpected selectivity. Moreover, circular dichroism and G4-FID assays suggested that the introduction of 1,2,4-oxadiazole moieties induce an important change in their binding mode, indeed, they probably act as groove binders [83].

More recently Zhou et al. developed a new class of 4,5-diazafluorene derivatives bearing 1,3-disubstituted thioxothiazolidinone-oxadiazole moieties as G4 binders [84]. The lead compound 54 (Figure 9) was deeply investigated using different biophysical assays. Despite careful design, these compounds resulted to be unpromising candidates. EMSA assays suggested the formation of higher-order 54/G4-DNA structures, but all the other experiments underlined its poor affinity $\left(\Delta \mathrm{Tm}=4{ }^{\circ} \mathrm{C}, 1 \mu \mathrm{M}\right.$ ligand concentration, 22AG) and selectivity towards $\mathrm{G} 4$ structures [84].

\section{Oxadiazoles Derivatives as Anticancer Agents without a Specific Target Identified}

When a novel bioactive compound is developed, identification of its biological targets and elucidation of its mechanism of action represent one of the most challenging goals of biomedical research. This is a common issue also in the development of oxadiazole-based drugs. In this context, among the different available approaches, structure-activity relationship analysis (SAR) is the most frequent starting point, to obtain biologically active compounds. According to the studies reported in the literature, three main strategies are used to modify oxadiazole scaffolds to improve their anticancer activities: (i) conjugation to other biologically active compounds, (ii) extension of aromatic surface to enhance the binding interactions, and (iii) introduction of sulfur-based functional groups, frequently found in FDA-approved drugs [85,86].

Conjugation to already known bioactive moieties is a simple strategy to improve biological properties of a specific substrate and, on this basis, Thasneem et al. reported the synthesis of a library of oxadiazoles covalently bound to Chalcone, an unsaturated carbonyl system that showed anti-inflammatory, anti-fungal and antitumor properties [87]. However, the obtained molecules have been tested against MCF-7 cells at different concentrations $(0.1,1,10,50$, and $100 \mu \mathrm{M})$ and $\mathrm{IC}_{50}$ ranging from 10 to $50 \mu \mathrm{M}$ have been measured.

Following the same approach, $\mathrm{Li}$ et al. synthesized a series of analogs of Imatinib, a Bcr-Abl tyrosine-kinase inhibitor employed for the treatment of chronic myelogenous leukemia [88], to individuate structural features that could further improve its anticancer activity [89]. They replaced the amide bond of Imatinib with a 1,2,3-triazole ring or 1,3,4-oxadiazole. All compounds were tested against K562, HL60 and KG-1a leukemia cell lines, however, all oxadiazole derivatives showed lower antiproliferative activity compared to Imatinib, suggesting a low antitumor potency of these structures.

Modification of oxadiazole scaffolds through conjugation to bioactive natural products also represents a promising approach. Mironov et al. exploited Furano-diterpenoids of the labdane series, an anti-inflammatory and anti-allergic drug-like [90], to build novel and potent derivatives [91]. In detail, 1,2,4-oxadiazoles were conjugated to labda-8(9),13,15-triene or labda-8(17),13,15-triene core and their antiproliferative activity and $\mathrm{GI}_{50}$ on CEM-13, MT-4 and U937 cells were measured [91]. From this screening, compound $\mathbf{5 5}$ (Figure 10) emerged for its remarkable toxicity, with $\mathrm{GI}_{50}$ values of $0.08 \pm 0.03 \mu \mathrm{M}$ on CEM-13, and $0.35 \pm 0.11 \mu \mathrm{M}$ on MT-4. Moreover, cytofluorimetric analysis demonstrated that treatment of U937 cells with 55 induced apoptosis in $46.8 \%$ of cells after $24 \mathrm{~h}$ and $84.4 \%$ after $48 \mathrm{~h}$ [91].

Following a similar approach, Markov et al. designed a series of 1,2,4-oxadiazoles modified with $18 \beta \mathrm{H}$-glycyrrhetinic acid (GA) [92], a pentacyclic triterpenoid with anti-inflammatory and antitumor activity [93]. In this study, the authors identified compound $\mathbf{5 6}$ (Figure 10) as the most toxic derivative, which differs from other molecules for the presence of pyridine bound to oxadiazole. Indeed, it showed 
significantly higher toxicity on $\mathrm{Hu} \mathrm{Tu}-80$ and HeLa cells, with $\mathrm{IC}_{50}$ of $3.8 \pm 0.3 \mu \mathrm{M}$ and $3.6 \pm 0.5 \mu \mathrm{M}$, respectively. Compound 56 also showed marked selectivity toward cancer cell lines compared to non-malignant ones, with a selectivity index greater than 12. Investigating the ability of $\mathbf{5 6}$ to induce apoptosis on HeLa (Annexin V assay), the accumulation of early and late apoptotic cells $(8.1 \%$ and $66.5 \%$ ) was observed. Moreover, low concentrations of 56 repressed tumor cell clonogenicity and motility, while high concentrations induced cell death through caspase-dependent apoptosis. Potential antitumor activity on $\mathbf{5 6}$ has been examined also in vivo, in murine metastatic melanoma model: animals were treated with five injections of $50 \mathrm{mg} / \mathrm{kg}$, and $70 \%$ reduction of metastasis growth has been observed, demonstrating that $\mathbf{5 6}$ represents a promising candidate in anticancer therapy.

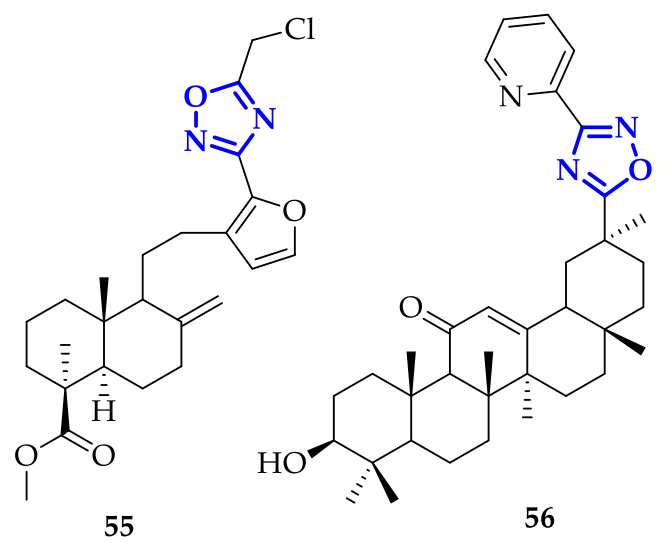

Figure 10. Oxadiazoles conjugated to bioactive molecules.

Despite encouraging results achieved with this approach, the modification of oxadiazole scaffolds by the conjugation of aromatic groups remains the most followed strategy. In the attempt to develop efficient anticancer agents, El-Din et al. synthesized oxadiazoles bearing a phenyl group in position 5 and a benzylic alcohol with a sulfonamide moiety in position 2 [94]. The authors evaluated the percentage of cell growth inhibition in NCl-58 cells at the concentration of $10 \mu \mathrm{M}$. It emerged that the introduction of p-chlorophenyl induced better efficiency (57\% of inhibition) compared to other derivatives. Furthermore, the authors found that n-propylsulfonamido displayed better outcomes compared to methyl sulfonamide, suggesting that higher activity could be achieved with longer alkyl chains. Due to the interesting results obtained in this work, the same authors decided to investigate how the introduction of one or two aromatic rings in positions 2 and 5 of the oxadiazole moiety could affect the anticancer activity of this class of compounds [95]. Each molecule has been screened at a single dose of $100 \mu \mathrm{M}$ against a panel of 60 cancer cell lines. From this screening 57 (Figure 11), emerged as the most efficient antiproliferative agent, highlighting that an extended aromatic surface (two phenyl rings with electron-donating substituents) could guarantee better anticancer activity.

Following the same approach, Salahuddin and co-workers synthesized a library of 1,3,4oxiadiazoles conjugated to quinolines and benzimidazole derivatives and measured their growth inhibition percentage (GP) towards a broad panel of cancer cell lines [96]. Compound 58 (Figure 11) emerged for its remarkable toxicity on HTC-116, with GP equal to $7.52 \mu \mathrm{M}$ and $\mathrm{GI}_{50}$ of $1.41 \mu \mathrm{M}$. Therefore, the introduction of quinoline moiety resulted in a promising path for the development of new anticancer drugs.

Conjugation to benzimidazole scaffold has been also exploited by Srinivas et al., obtaining compound 59 (Figure 11), highly toxic on A549 cells, with $\mathrm{IC}_{50}$ of $0.12 \pm 0.01 \mu \mathrm{M}$ [97].

Gurupadaswamy et al. demonstrated that the antitumor activity can be improved by increasing the number of aromatic rings, despite a lower degree of conjugation. The authors identified the potent 2,5-di(4-aryloylarylox-ymethyl)-1,3,4-oxadiazole DAO-9 (Figure 11), containing five aromatic rings, that showed high toxicity against leukemia at only $10 \mu \mathrm{M}$ concentration [98]. To study its effect in vivo, $50 \mathrm{mg} / \mathrm{kg}$ body weight of DAO-9 were administered in murine ascites tumor (MAC) identifying a 
significant reduction in tumor volume in a dose-dependent manner [99]. Furthermore, to assess its ability to induce apoptosis, MAC cells were treated with $0,0.5$, and $10 \mu \mathrm{M}$ of DAO-9 observing an increase in apoptosis from 10 to $21 \%$. Moreover, treatment of MAC cells induced nuclear condensation and increased expression of p53, Bax, Bad and cyt c, a series of pro-apoptotic proteins [99].<smiles>COc1ccc(-c2nnc(Nc3cc(C)cc(C)c3)o2)cc1</smiles>

57<smiles>COc1ccc(-c2nnc(-c3ccc(C(F)(F)F)nc3N)o2)cc1</smiles>

61<smiles>CC(C)(C)c1noc(-c2ccc(Nc3n[nH]c4nc(-c5ccccc5)nc(N)c34)cc2)n1</smiles>

63<smiles>N#Cc1ccc(-c2nc(-c3ccc4nc(-c5ccc(-c6cnco6)cc5)[nH]c4c3)no2)cc1</smiles><smiles>CC(=O)Oc1ccccc1-c1nnc(COc2ccc(Cl)cc2)o1</smiles>

AMK OX-12<smiles>O=C(Nc1nnc(-c2ccccc2)o1)c1ccccc1</smiles>

60<smiles>Cn1cc(-c2noc(-c3cn(C)c4ncc(Br)cc34)n2)c2cc(Cl)ccc21</smiles><smiles>ClC1=C(c2nnc(-c3ccccc3)o2)CCCc2ccccc21</smiles>

64

Figure 11. Oxadiazoles with extended aromatic system.

Tiwari et al. synthesized a library of disubstituted 1,3,4-oxadiazoles, containing two phenyl rings with various substituents, and investigated their biological activity both in vitro and in vivo [100]. Among them, AMK OX-12 (Figure 11) showed a significant toxic effect on Hep2 cells, with $\mathrm{IC}_{50}$ of $0.0007 \mu \mathrm{M}$ after $72 \mathrm{~h}$ of incubation and, at the same time, displayed low toxicity $\left(\mathrm{IC}_{50}>50 \mu \mathrm{M}\right)$ on non-malignant cells (Chang Liver and V79). The anticancer ability of AMK OX-12 was also confirmed by studies in vivo, in which its reduction of tumor growth in mice was comparable to Cisplatin.

Modification of the 1,3,4-oxadiazole scaffold with only two phenyl rings resulted to be a successful strategy also for Mochona et al., that individuated compound 60 (Figure 11) as the best of the series with the highest toxicity in particular on PC-3 cells $\left(\mathrm{IC}_{50}=0.22 \mu \mathrm{M}\right)$ [101]. Subsequently, it has been verified that 60 induced apoptosis and cell cycle arrest at G0/G1 and S phases.

Introduction of 2-substituted pyridines, as reported by Kumar et al., led to promising results as demonstrated by proving the efficiency of these compounds against HeLa, DU145, HepG2, 
and MDA-MB-231 cancer cell lines [102]. Among them, 61 (Figure 11) showed higher toxicity in particular on DU145 cells with an $\mathrm{IC}_{50}$ value of $10.7 \mu \mathrm{M}$. This enhanced activity has been attributed to both the presence of a trifluoromethyl group, that improves lipophilicity, and to the electron-donating effect of methoxy substituent [102].

On the contrary, Cascioferro et al. extended the aromatic system of 1,2,4-oxadiazole exploiting indole and azaindole derivatives with different types of substituents, including halogen atoms and methoxy units [103]. After a preliminary screening on HCT-116 cells, compound 62 (Figure 11) emerged as the most potent, displaying high toxicity on different cell lines and specifically on MCF-7 cells with $\mathrm{IC}_{50}$ of $0.65 \pm 0.05 \mu \mathrm{M}$. Furthermore, authors demonstrated that 62 caused cell cycle arrest (more than $60 \%$ ) at G0/G1 phase and its ability to induce apoptosis was confirmed through Annexin V/PI dual staining method, followed by cytofluorimetric analysis [103].

Another interesting example of modification with aza-based heterocycles was reported by Maftei et al. [104]. They synthesized different 1,2,4-oxadiazoles covalently bound to pyrimidines and evaluated their toxicity against 12 human cancer cell lines obtaining moderate to low toxicity. Best results were achieved with compound 63 (Figure 11), with $\mathrm{IC}_{50}$ below $9.3 \mu \mathrm{M}$ against all tested cell lines and higher activity on ovarian adenocarcinoma OVXF $899\left(\mathrm{IC}_{50}=2.76 \mu \mathrm{M}\right)$ and colorectal carcinoma CXF HT-29 $\left(\mathrm{IC}_{50}=2.90 \mu \mathrm{M}\right)$ cells.

Yadagiri et al. synthesized different benzosuberones functionalized with 1,3,4-oxadiazole, 1,3,4-thiadiazole and 1,2,4-triazole moieties as alternative to commonly used aromatic rings [105]. All compounds have been tested against HeLa, MDA-MB-231, PANC1, and A549 cancer cells, and the viability of cell growth was calculated by SRB cell proliferative assay. Among them, oxadiazole derivative 64 (Figure 11) displayed the highest cell growth inhibition, with a more pronounced effect on HeLa cells $\left(\mathrm{IC}_{50}=0.079 \pm 0.002 \mu \mathrm{M}\right)[105]$.

The presence of an aromatic system is not the only important structural feature: it has been discovered that also oxadiazoles conjugating to sulfur atoms present interesting biological properties. Guogang et al. obtained promising results after the synthesis of a library of 1,2,4-triazoles and 1,3,4-oxadiazoles, including a series of 5-thioxo-1,3,4-oxadiazole analogs, differing for the kind of phenyl substituent and the type of thio-derivative introduced on the lateral chain in position 5 [106]. Comparing 1,2,4-triazoles and 1,3,4-oxadiazole analogs, 1,2,4-triazoles have lower toxicity. Indeed, the highest antiproliferative activity was recorded by 65 (Figure 12) on K562 cells, showing an 85\% inhibition ratio [106].

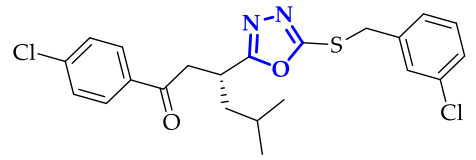

65

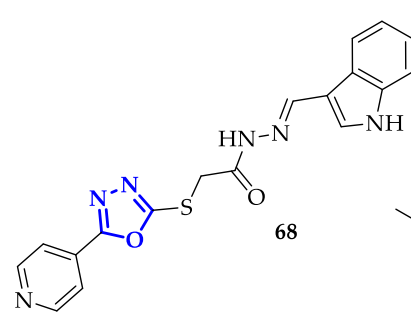

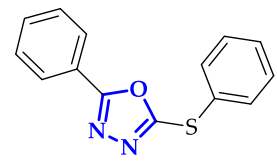

66
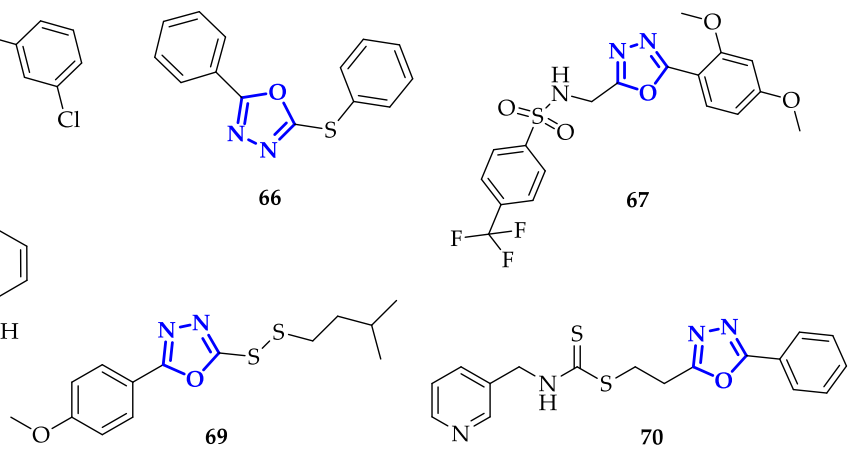

Figure 12. Oxadiazoles containing sulfur-based functional groups.

Yonova et al. designed a library of 1,3,4-oxadiazoles conjugated to diaryl and heteroaryl sulfides and evaluated their anticancer activity on MCF-10 and MCF-10A breast cancer cell lines [107]. The most potent compound of the series was $\mathbf{6 6}$ (Figure 12), with an $\mathrm{EC}_{50}$ value of $7.9 \mu \mathrm{M}$.

In an attempt to improve both bioavailability and the antitumor effects, Kumar et al. synthesized different 2,5-disubstituted-1,3,4-oxadiazoles, containing both sulfonamide moiety and fluorine 
atoms, to increase lipophilicity and cellular uptake [108]. Sulfonamide groups, present in several FDA-approved drugs, were often used to improve drug-like design [86,109]. In this context, 67 (Figure 12) stood out for a drastic reduction in cell survival percentage, which was below $30 \%$ in the case of K562 cells and $42.52 \%$ and $40.68 \%$ with Colo-205 and MDA-MB 231, respectively. This result suggests that the presence of electron-donating substituents on this kind of scaffold increased anti-cancer toxicity.

Khalil et al. synthesized thirty-six 5-pyridyl-1,3,4-oxadiazolethiols, functionalized with aliphatic, hydrazino, hydrazide, heterocyclic, or sulphonamide moieties to explore their effect against breast cancer cell lines [110]. All the tested molecules presented remarkable toxicity towards MCF-7, with $\mathrm{IC}_{50}$ values ranging from 0.08 to $0.01 \mu \mathrm{M}$. The highest efficiency was measured for compound 68 (Figure 12), characterized by an indolyl group, that evidenced, once again, the importance of an extended aromatic scaffold.

Zhao et al. designed a library of non-symmetrical disulfides containing 1,3,4-oxadiazole scaffold and tested their antiproliferative activity against SMMC-7721, HeLa, and A549 cancer cell lines [111]. In general, only moderate toxicity was observed, except with compound 69 (Figure 12), that presented interesting selectivity towards SMMC-7721 cells, with $\mathrm{IC}_{50}=3.40 \mu \mathrm{M}$.

Another interesting functional group involving sulfur atom is represented by dithiocarbamate, recently emerged for its promising anticancer properties [112]. With the aim to improve anticancer efficacy, Li et al. synthesized novel heteroarylmethylcarbamodithioates containing 1,3,4-oxadiazole scaffold, and evaluated their biological activity on hepatoma cells Bel-7402, breast cancer cells SK-BR-3 and MDA-MB-468 [113]. During this screening, compound 70 (Figure 12) resulted to be the most toxic with marked preference for Bel-7402 $\left(\mathrm{IC}_{50}=1.23 \pm 0.49 \mu \mathrm{M}\right)$ and SK-BR-3 $\left(\mathrm{IC}_{50}=0.58 \pm 0.05 \mu \mathrm{M}\right)$ cells. Due to its promising activity, $\mathbf{7 0}$ has been further tested against other cancer cell lines, including lung cancer (H1299, H460, H522), hepatoma (Bel-7402), breast (MDA-MB-468, SK-BR-3), colorectal (COLO205, HCT-8, HCT-116, SW620) and prostate (DU145, PC3) in comparison with non-malignant cell lines (LO2 and 293). 70 presented good toxicity in all cancerous cells, with $\mathrm{IC}_{50}$ values from 0.39 to $7.91 \mu \mathrm{M}$, while $\mathrm{IC}_{50}$ values above $9 \mu \mathrm{M}$ were measured in normal cells. Moreover, 70 caused chromatin condensation, a clear sign of induced apoptosis, and stopped cell cycle at G2/M phase, both in Bel-7402 and PC-3 cells. Further analysis evidenced that this substrate has a mechanism of action similar to the well-known Taxol [114]; indeed, treatment with 70 increased levels of MPM-2 and phosphorylated histone H3, two specific mitotic molecular markers that indicate mitotic arrest. This was further confirmed by the generation of Supernumerary Centrosomes and Multipolar Spindles formation upon treatment with $\mathbf{7 0}$, an abnormal behavior observed also with Taxol, highlighting $\mathbf{7 0}$ as a promising candidate for the treatment of different kinds of tumors [113].

As an alternative to previously reported approaches, modification with carbohydrates is a common strategy used to improve the activity of bioactive molecules and it has been exploited also in the case of 1,2,4-oxadiazoles. Avanzo et al. reported some 1,2,4-oxadiazoles conjugated to D-ribofuranoside [115] and tested their antiproliferative activity against A549, HBL-100, HeLa, SW1573, T-47D, and WiDr cancer cell lines. However, also these compounds presented only a moderate anticancer effect, with $\mathrm{IC}_{50}$ ranging from $4 \mu \mathrm{M}$ to over $100 \mu \mathrm{M}$.

Another interesting functionalization of 1,3,4-oxadiazoles scaffold is the conjugation of fatty acid analogs [116]. Hassan and co-workers described the synthesis of a library of 1,3,4-oxadiazol-2(3H)-one with fatty acids with different chain-lengths and numbers of double bonds, chosen for their promising anticancer properties [117]. Antiproliferative activity of each molecule has been tested against HeLa, MDA-MB-231, and KCL-22 (Lymphoblastoid) cells for $48 \mathrm{~h}$. Authors measured $\mathrm{IC}_{50}$ values in the 6-50 $\mu \mathrm{M}$ range, with the highest toxicity observed in presence of $71\left(\mathrm{IC}_{50}=6.3 \pm 1.1 \mu \mathrm{M}\right.$ on HeLa cells; $\mathrm{IC}_{50}=8.3 \pm 1.2 \mu \mathrm{M}$ on KCL-22; $\mathrm{IC}_{50}=9.6 \pm 1.2 \mu \mathrm{M}$ on MDA-MB-231; Figure 13), characterized by a 16-carbon atoms chain covalently bound to 1,3,4-oxadiazol-2(3H)-one. This result underlined that the presence of a cis-double bond and a hydroxy group are two key structural features to guarantee more potent activity, despite the toxicity of $\mathbf{7 1}$ resulted to be lower compared to reference compound doxorubicin. Moreover, fluorescence microscopy micrographs, in agreement with previous 
experiments, showed that $\mathbf{7 1}$ was able to induce apoptosis with higher efficiency compared to other compounds of the library.

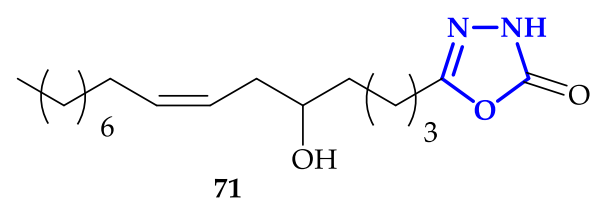

Figure 13. Oxadiazole conjugated to long-chain fatty acid.

In this context, several signs of progress were accomplished in the past years as confirmed by positive results described above. However, to develop novel and specific drug-like, a lot of effort is still required to identify other modifications and structural elements that could guarantee not only high antitumor potency but also interaction with specific and defined targets.

\section{Conclusions}

The overview of oxadiazoles anticancer activity reported herein highlights the extensively use of this class of heterocyclic compounds in medicinal chemistry, further confirmed by the presence of several commercially available drugs based on these interesting scaffolds.

The reasons for their success lie in an efficient and simple synthesis, high versatility, giving rise to elevated structural diversity, and remarkable stability, a key feature for in vivo applications. Thanks to its structural nature, oxadiazoles easily interact with bio-targets establishing $\pi$-stacking interactions or forming strong hydrogen bonds.

Despite the existence of different regioisomers, 1,2,4 and 1,3,4-oxadiazoles represent the most interesting derivatives for biological application. Recently, it has been demonstrated that oxadiazoles can interact with specific targets, as demonstrated for enzymes, globular proteins and DNA structures. This correspondence helped to clarify the origin of cytotoxicity of these compounds, allowing the improvement of drug design in relationship with the identified target.

Furthermore, a broad number of oxadiazole ligands with promising anticancer activity have been developed despite their mechanism of action must be still clarified. It should be underlined that oxadiazoles that present relevant cytotoxicity are characterized by some common structural features: in particular, described molecules present modification with bioactive compounds, an extended aromatic surface, or the presence of a sulfur-based functional group. These results evidence the important progresses achieved in the last few years, however, a lot of effort should be dedicated to further optimize these chemical structures in order to enhance their potency and to improve the selectivity towards specific target.

Funding: This research received no external funding.

Acknowledgments: V.P. was supported by a PostDoc fellowship funded by M. Freccero Laboratory, Chemistry Department, UNIPV.

Conflicts of Interest: The authors declare no conflict of interest.

\section{References}

1. Jampilek, J. Heterocycles in Medicinal Chemistry. Molecules 2019, 24, 3839. [CrossRef]

2. Berger, J.; Li, M.; Berger, S.; Meilak, M.; Rientjes, J.; Currie, P.D. Effect of Ataluren on dystrophin mutations. J. Cell. Mol. Med. 2020, 24, 6680-6689. [CrossRef]

3. Caputo, F.; Corbetta, S.; Piccolo, O.; Vigo, D. Seeking for Selectivity and Efficiency: New Approaches in the Synthesis of Raltegravir. Org. Process Res. Dev. 2020, 24, 1149-1156. [CrossRef]

4. Khallaf, A.; Wang, P.; Liu, H.; Zhuo, S.; Zhu, H. 1,2,4-Oxadiazole ring-containing pyridylpyrazole-4carboxamides: Synthesis and evaluation as novel insecticides of the anthranilic diamide family. J. Heterocycl. Chem. 2020, 57, 1981-1992. [CrossRef] 
5. Fershtat, L.L.; Makhova, N.N. 1,2,5-Oxadiazole-Based High-Energy-Density Materials: Synthesis and Performance. ChemPlusChem 2020, 85, 13-42. [CrossRef]

6. Salassa, G.; Terenzi, A. Metal Complexes of Oxadiazole Ligands: An Overview. Int. J. Mol. Sci. 2019, $20,3483$. [CrossRef] [PubMed]

7. Boström, J.; Hogner, A.; Llinàs, A.; Wellner, E.; Plowright, A.T. Oxadiazoles in Medicinal Chemistry. J. Med. Chem. 2012, 55, 1817-1830. [CrossRef]

8. Biernacki, K.; Daśko, M.; Ciupak, O.; Kubiński, K.; Rachon, J.; Demkowicz, S. Novel 1,2,4-Oxadiazole Derivatives in Drug Discovery. Pharmaceuticals 2020, 13, 111. [CrossRef] [PubMed]

9. Tassinari, M.; Lena, A.; Butovskaya, E.; Pirota, V.; Nadai, M.; Freccero, M.; Doria, F.; Richter, S.N. A Fragment-Based Approach for the Development of G-Quadruplex Ligands: Role of the Amidoxime Moiety. Molecules 2018, 23, 1874. [CrossRef] [PubMed]

10. Zhu, W.; Bao, X.; Ren, H.; Liao, P.; Yan, Y.; Wang, L.; Chen, Z. Design, synthesis, and pharmacological evaluation of 5-oxo-1,2,4-oxadiazole derivatives as AT1 antagonists with antihypertension activities. Clin. Exp. Hypertens. 2016, 38, 435-442. [CrossRef]

11. Ibrahim, M.T.; Uzairu, A.; Shallangwa, G.A.; Ibrahim, A. In-silico studies of some oxadiazoles derivatives as anti-diabetic compounds. J. King Saud Univ.-Sci. 2020, 32, 423-432. [CrossRef]

12. Chawla, G.; Naaz, B.; Siddiqui, A.A. Exploring 1,3,4-Oxadiazole Scaffold for Anti-inflammatory and Analgesic Activities: A Review of Literature From 2005-2016. Mini Rev. Med. Chem. 2018, 18, 216-233. [CrossRef] [PubMed]

13. Bajaj, S.; Asati, V.; Singh, J.; Roy, P.P. 1,3,4-Oxadiazoles: An emerging scaffold to target growth factors, enzymes and kinases as anticancer agents. Eur. J. Med. Chem. 2015, 97, 124-141. [CrossRef] [PubMed]

14. Glomb, T.; Szymankiewicz, K.; Świątek, P. Anti-Cancer Activity of Derivatives of 1,3,4-Oxadiazole. Molecules 2018, 23, 3361. [CrossRef] [PubMed]

15. Boström, J.; Hogner, A.; Schmitt, S. Do Structurally Similar Ligands Bind in a Similar Fashion? J. Med. Chem. 2006, 49, 6716-6725. [CrossRef]

16. Ceyhan, B.B.; Karakurt, S. Effect of oxolamine on cough sensitivity in COPD patients. Respir. Med. 2002, 96, 61-63. [CrossRef]

17. Landfeldt, E.; Sejersen, T.; Tulinius, M. A mini-review and implementation model for using ataluren to treat nonsense mutation Duchenne muscular dystrophy. Acta Paediatr. 2019, 108, 224-230. [CrossRef]

18. Konstan, M.W.; VanDevanter, D.R.; Rowe, S.M.; Wilschanski, M.; Kerem, E.; Sermet-Gaudelus, I.; DiMango, E.; Melotti, P.; McIntosh, J.; De Boeck, K. Efficacy and safety of ataluren in patients with nonsense-mutation cystic fibrosis not receiving chronic inhaled aminoglycosides: The international, randomized, double-blind, placebo-controlled Ataluren Confirmatory Trial in Cystic Fibrosis (ACT CF). J. Cyst. Fibros. 2020, 19, 595-601. [CrossRef]

19. Tully, W.R.; Gardner, C.R.; Gillespie, R.J.; Westwood, R. 2-(Oxadiazolyl)- and 2-(thiazolyl)imidazo [1,2-a]pyrimidines as agonists and inverse agonists at benzodiazepine receptors. J. Med. Chem. 1991, 34, 2060-2067. [CrossRef]

20. Cecchini, D.M.; Martinez, M.G.; Morganti, L.M.; Rodriguez, C.G. Antiretroviral Therapy Containing Raltegravir to Prevent Mother-to-Child Transmission of HIV in Infected Pregnant Women. Infect. Dis. Rep. 2017, 9, 7017. [CrossRef]

21. Toombs, J.M.; Van den Abbeele, K.; Democratis, J.; Merricks, R.; Mandal, A.K.J.; Missouris, C.G. COVID-19 in three people living with HIV in the United Kingdom. J. Med. Virol. 2020, 1-3. [CrossRef] [PubMed]

22. Calligari, P.; Bobone, S.; Ricci, G.; Bocedi, A. Molecular Investigation of SARS-CoV-2 Proteins and Their Interactions with Antiviral Drugs. Viruses 2020, 12, 445. [CrossRef]

23. Lloyd, M.D. High-Throughput Screening for the Discovery of Enzyme Inhibitors. J. Med. Chem. 2020, 63, 10742-10772. [CrossRef]

24. Yoo, Y.J.; Feng, Y.; Kim, Y.H.; Yagonia, C.F.J. Specificity of Enzymes. In Fundamentals of Enzyme Engineering; Springer: Dordrecht, The Netherlands, 2017; pp. 111-125.

25. Baig, M.H.; Adil, M.; Khan, R.; Dhadi, S.; Ahmad, K.; Rabbani, G.; Bashir, T.; Imran, M.A.; Husain, F.M.; Lee, E.J.; et al. Enzyme targeting strategies for prevention and treatment of cancer: Implications for cancer therapy. Semin. Cancer Biol. 2019, 56, 1-11. [CrossRef]

26. Eitsuka, T.; Nakagawa, K.; Kato, S.; Ito, J.; Otoki, Y.; Takasu, S.; Shimizu, N.; Takahashi, T.; Miyazawa, T. Modulation of Telomerase Activity in Cancer Cells by Dietary Compounds: A Review. Int. J. Mol. Sci. 2018, 19, 478. [CrossRef] 
27. Zheng, Q.-Z.; Zhang, X.-M.; Xu, Y.; Cheng, K.; Jiao, Q.-C.; Zhu, H.-L. Synthesis, biological evaluation, and molecular docking studies of 2-chloropyridine derivatives possessing 1,3,4-oxadiazole moiety as potential antitumor agents. Bioorganic Med. Chem. 2010, 18, 7836-7841. [CrossRef]

28. Gillis, A.J.; Schuller, A.P.; Skordalakes, E. Structure of the Tribolium castaneum telomerase catalytic subunit TERT. Nature 2008, 455, 633-637. [CrossRef]

29. Zhang, X.-M.; Qiu, M.; Sun, J.; Zhang, Y.-B.; Yang, Y.-S.; Wang, X.-L.; Tang, J.-F.; Zhu, H.-L. Synthesis, biological evaluation, and molecular docking studies of 1,3,4-oxadiazole derivatives possessing 1,4-benzodioxan moiety as potential anticancer agents. Bioorganic Med. Chem. 2011, 19, 6518-6524. [CrossRef]

30. Zhang, Y.-B.; Wang, X.-L.; Liu, W.; Yang, Y.-S.; Tang, J.-F.; Zhu, H.-L. Design, synthesis and biological evaluation of heterocyclic azoles derivatives containing pyrazine moiety as potential telomerase inhibitors. Bioorganic Med. Chem. 2012, 20, 6356-6365. [CrossRef]

31. Sun, J.; Zhu, H.; Yang, Z.-M.; Zhu, H.-L. Synthesis, molecular modeling and biological evaluation of 2-aminomethyl-5-(quinolin-2-yl)-1,3,4-oxadiazole-2(3H)-thione quinolone derivatives as novel anticancer agent. Eur. J. Med. Chem. 2013, 60, 23-28. [CrossRef]

32. Mboge, M.Y.; Mahon, B.P.; McKenna, R.; Frost, S.C. Carbonic Anhydrases: Role in pH Control and Cancer. Metabolites 2018, 8, 19. [CrossRef] [PubMed]

33. Krasavin, M.; Shetnev, A.; Sharonova, T.; Baykov, S.; Tuccinardi, T.; Kalinin, S.; Angeli, A.; Supuran, C.T. Heterocyclic periphery in the design of carbonic anhydrase inhibitors: 1,2,4-Oxadiazol-5-yl benzenesulfonamides as potent and selective inhibitors of cytosolic hCA II and membrane-bound hCA IX isoforms. Bioorganic Chem. 2018, 76, 88-97. [CrossRef] [PubMed]

34. Krasavin, M.; Shetnev, A.; Sharonova, T.; Baykov, S.; Kalinin, S.; Nocentini, A.; Sharoyko, V.; Poli, G.; Tuccinardi, T.; Presnukhina, S.; et al. Continued exploration of 1,2,4-oxadiazole periphery for carbonic anhydrase-targeting primary arene sulfonamides: Discovery of subnanomolar inhibitors of membrane-bound hCA IX isoform that selectively kill cancer cells in hypoxic environment. Eur. J. Med. Chem. 2019, 164, 92-105. [CrossRef] [PubMed]

35. Delcuve, G.P.; Khan, D.H.; Davie, J.R. Roles of histone deacetylases in epigenetic regulation: Emerging paradigms from studies with inhibitors. Clin. Epigenetics 2012, 4, 5. [CrossRef]

36. Ruzzolini, J.; Laurenzana, A.; Andreucci, E.; Peppicelli, S.; Bianchini, F.; Carta, F.; Supuran, C.T.; Romanelli, M.N.; Nediani, C.; Calorini, L. A potentiated cooperation of carbonic anhydrase IX and histone deacetylase inhibitors against cancer. J. Enzym. Inhib. Med. Chem. 2020, 35, 391-397. [CrossRef]

37. Verza, F.A.; Das, U.; Fachin, A.L.; Dimmock, J.R.; Marins, M. Roles of Histone Deacetylases and Inhibitors in Anticancer Therapy. Cancers 2020, 12, 1664. [CrossRef]

38. Rajak, H.; Agarawal, A.; Parmar, P.; Thakur, B.S.; Veerasamy, R.; Sharma, P.C.; Kharya, M.D. 2,5-Disubstituted1,3,4-oxadiazoles/thiadiazole as surface recognition moiety: Design and synthesis of novel hydroxamic acid based histone deacetylase inhibitors. Bioorganic Med. Chem. Lett. 2011, 21, 5735-5738. [CrossRef]

39. Valente, S.; Trisciuoglio, D.; De Luca, T.; Nebbioso, A.; Labella, D.; Lenoci, A.; Bigogno, C.; Dondio, G.; Miceli, M.; Brosch, G.; et al. 1,3,4-Oxadiazole-Containing Histone Deacetylase Inhibitors: Anticancer Activities in Cancer Cells. J. Med. Chem. 2014, 57, 6259-6265. [CrossRef]

40. Kavanaugh, S.A.; White, L.A.; Kolesar, J.M. Vorinostat: A novel therapy for the treatment of cutaneous T-cell lymphoma. Am. J. Health-Syst. Pharm. 2010, 67, 793-797. [CrossRef]

41. Benson, E.K.; Mungamuri, S.K.; Attie, O.; Kracikova, M.; Sachidanandam, R.; Manfredi, J.J.; Aaronson, S.A. p53-dependent gene repression through p21 is mediated by recruitment of E2F4 repression complexes. Oncogene 2014, 33, 3959-3969. [CrossRef]

42. Cai, J.; Wei, H.; Hong, K.H.; Wu, X.; Cao, M.; Zong, X.; Li, L.; Sun, C.; Chen, J.; Ji, M. Discovery and preliminary evaluation of 2-aminobenzamide and hydroxamate derivatives containing 1,2,4-oxadiazole moiety as potent histone deacetylase inhibitors. Eur. J. Med. Chem. 2015, 96, 1-13. [CrossRef] [PubMed]

43. Pidugu, V.R.; Yarla, N.S.; Pedada, S.R.; Kalle, A.M.; Satya, A.K. Design and synthesis of novel HDAC8 inhibitory 2,5-disubstituted-1,3,4-oxadiazoles containing glycine and alanine hybrids with anti cancer activity. Bioorganic Med. Chem. 2016, 24, 5611-5617. [CrossRef] [PubMed]

44. Yang, F.; Shan, P.; Zhao, N.; Ge, D.; Zhu, K.; Jiang, C.-S.; Li, P.; Zhang, H. Development of hydroxamate-based histone deacetylase inhibitors containing 1,2,4-oxadiazole moiety core with antitumor activities. Bioorganic Med. Chem. Lett. 2019, 29, 15-21. [CrossRef] [PubMed] 
45. Yang, Z.; Shen, M.; Tang, M.; Zhang, W.; Cui, X.; Zhang, Z.; Pei, H.; Li, Y.; Hu, M.; Bai, P.; et al. Discovery of 1,2,4-oxadiazole-Containing hydroxamic acid derivatives as histone deacetylase inhibitors potential application in cancer therapy. Eur. J. Med. Chem. 2019, 178, 116-130. [CrossRef]

46. Bhullar, K.S.; Lagarón, N.O.; McGowan, E.M.; Parmar, I.; Jha, A.; Hubbard, B.P.; Rupasinghe, H.P.V. Kinase-targeted cancer therapies: Progress, challenges and future directions. Mol. Cancer 2018, 17, 48. [CrossRef]

47. Zhang, S.; Luo, Y.; He, L.-Q.; Liu, Z.-J.; Jiang, A.-Q.; Yang, Y.-H.; Zhu, H.-L. Synthesis, biological evaluation, and molecular docking studies of novel 1,3,4-oxadiazole derivatives possessing benzotriazole moiety as FAK inhibitors with anticancer activity. Bioorganic Med. Chem. 2013, 21, 3723-3729. [CrossRef]

48. Barlaam, B.; Cosulich, S.; Delouvrié, B.; Ellston, R.; Fitzek, M.; Germain, H.; Green, S.; Hancox, U.; Harris, C.S.; Hudson, K.; et al. Discovery of 1-(4-(5-(5-amino-6-(5-tert-butyl-1,3,4-oxadiazol-2-yl) pyrazin-2 -yl)-1-ethyl-1,2,4-triazol-3-yl)piperidin-1-yl)-3-hydroxypropan-1-one (AZD8835): A potent and selective inhibitor of PI3K $\alpha$ and PI3K $\delta$ for the treatment of cancers. Bioorganic Med. Chem. Lett. 2015, 25, 5155-5162. [CrossRef]

49. Han, M.; Li, S.; Ai, J.; Sheng, R.; Hu, Y.; Geng, M. Discovery of 4-chloro-3-(5-(pyridin-3-yl)-1,2,4- oxadiazole-3-yl) benzamides as novel RET kinase inhibitors. Bioorganic Med. Chem. Lett. 2016, 26, 5679-5684. [CrossRef]

50. Liu, K.; Lu, X.; Zhang, H.-J.; Sun, J.; Zhu, H.-L. Synthesis, molecular modeling and biological evaluation of 2-(benzylthio)-5-aryloxadiazole derivatives as anti-tumor agents. Eur. J. Med. Chem. 2012, 47, 473-478. [CrossRef]

51. Dokla, E.M.E.; Fang, C.S.; Abouzid, K.A.M.; Chen, C.S. 1,2,4-Oxadiazole derivatives targeting EGFR and c-Met degradation in TKI resistant NSCLC. Eur. J. Med. Chem. 2019, 182, 111607. [CrossRef]

52. Zhang, X.; Gureasko, J.; Shen, K.; Cole, P.A.; Kuriyan, J. An allosteric mechanism for activation of the kinase domain of epidermal growth factor receptor. Cell 2006, 125, 1137-1149. [CrossRef] [PubMed]

53. Sigismund, S.; Avanzato, D.; Lanzetti, L. Emerging functions of the EGFR in cancer. Mol. Oncol. 2018, 12, 3-20. [CrossRef] [PubMed]

54. Polothi, R.; Raolji, G.S.B.; Kuchibhotla, V.S.; Sheelam, K.; Tuniki, B.; Thodupunuri, P. Synthesis and biological evaluation of 1,2,4-oxadiazole linked 1,3,4-oxadiazole derivatives as tubulin binding agents. Synth. Commun. 2019, 49, 1603-1612. [CrossRef]

55. Ozcan, S.; Kazi, A.; Marsilio, F.; Fang, B.; Guida, W.C.; Koomen, J.; Lawrence, H.R.; Sebti, S.M. Oxadiazole-isopropylamides as Potent and Noncovalent Proteasome Inhibitors. J. Med. Chem. 2013, 56, 3783-3805. [CrossRef]

56. Zhang, N.; Yin, Y.; Xu, S.-J.; Chen, W.-S. 5-Fluorouracil: Mechanisms of resistance and reversal strategies. Molecules 2008, 13, 1551-1569. [CrossRef] [PubMed]

57. Du, Q.-R.; Li, D.-D.; Pi, Y.-Z.; Li, J.-R.; Sun, J.; Fang, F.; Zhong, W.-Q.; Gong, H.-B.; Zhu, H.-L. Novel 1,3,4-oxadiazole thioether derivatives targeting thymidylate synthase as dual anticancer/antimicrobial agents. Bioorganic Med. Chem. 2013, 21, 2286-2297. [CrossRef]

58. Subba Rao, A.V.; Vishnu Vardhan, M.V.P.S.; Subba Reddy, N.V.; Srinivasa Reddy, T.; Shaik, S.P.; Bagul, C.; Kamal, A. Synthesis and biological evaluation of imidazopyridinyl-1,3,4-oxadiazole conjugates as apoptosis inducers and topoisomerase II $\alpha$ inhibitors. Bioorganic Chem. 2016, 69, 7-19. [CrossRef]

59. Abd El Hameid, M.K. Design, Synthesis, and Screening of 5-Aryl-3-(2-(pyrrolyl)thiophenyl)-1,2,4-oxadiazoles as Potential Antitumor Molecules on Breast Cancer MCF-7 Cell Line. Chem. Pharm. Bull. 2018, 66, 1181-1195. [CrossRef]

60. Dai, H.; Sinclair, D.A.; Ellis, J.L.; Steegborn, C. Sirtuin activators and inhibitors: Promises, achievements, and challenges. Pharmacol. Ther. 2018, 188, 140-154. [CrossRef]

61. Carafa, V.; Rotili, D.; Forgione, M.; Cuomo, F.; Serretiello, E.; Hailu, G.S.; Jarho, E.; Lahtela-Kakkonen, M.; Mai, A.; Altucci, L. Sirtuin functions and modulation: From chemistry to the clinic. Clin. Epigenetics 2016, 8, 61. [CrossRef]

62. Schlicker, C.; Boanca, G.; Lakshminarasimhan, M.; Steegborn, C. Structure-based development of novel sirtuin inhibitors. Aging 2011, 3, 852-872. [CrossRef] [PubMed]

63. Moniot, S.; Forgione, M.; Lucidi, A.; Hailu, G.S.; Nebbioso, A.; Carafa, V.; Baratta, F.; Altucci, L.; Giacché, N.; Passeri, D.; et al. Development of 1,2,4-Oxadiazoles as Potent and Selective Inhibitors of the Human Deacetylase Sirtuin 2: Structure-Activity Relationship, X-ray Crystal Structure, and Anticancer Activity. J. Med. Chem. 2017, 60, 2344-2360. [CrossRef] [PubMed]

64. Janke, C.; Magiera, M.M. The tubulin code and its role in controlling microtubule properties and functions. Nat. Rev. Mol. Cell Biol. 2020, 21, 307-326. [CrossRef] [PubMed] 
65. Ferrara, R.; Pilotto, S.; Peretti, U.; Caccese, M.; Kinspergher, S.; Carbognin, L.; Karachaliou, N.; Rosell, R.; Tortora, G.; Bria, E. Tubulin inhibitors in non-small cell lung cancer: Looking back and forward. Expert Opin Pharm. 2016, 17, 1113-1129. [CrossRef] [PubMed]

66. Haider, K.; Rahaman, S.; Yar, M.S.; Kamal, A. Tubulin inhibitors as novel anticancer agents: An overview on patents (2013-2018). Expert Opin. Ther. Pat. 2019, 29, 623-641. [CrossRef]

67. Martino, E.; Casamassima, G.; Castiglione, S.; Cellupica, E.; Pantalone, S.; Papagni, F.; Rui, M.; Siciliano, A.M.; Collina, S. Vinca alkaloids and analogues as anti-cancer agents: Looking back, peering ahead. Bioorganic Med. Chem. Lett. 2018, 28, 2816-2826. [CrossRef]

68. Cummings, J.; Zweifel, M.; Smith, N.; Ross, P.; Peters, J.; Rustin, G.; Price, P.; Middleton, M.R.; Ward, T.; Dive, C. Evaluation of cell death mechanisms induced by the vascular disrupting agent OXi4503 during a phase I clinical trial. Br. J. Cancer 2012, 106, 1766-1771. [CrossRef]

69. Ji, Y.T.; Liu, Y.N.; Liu, Z.P. Tubulin colchicine binding site inhibitors as vascular disrupting agents in clinical developments. Curr. Med. Chem. 2015, 22, 1348-1360. [CrossRef]

70. Inglis, D.J.; Lavranos, T.C.; Beaumont, D.M.; Leske, A.F.; Brown, C.K.; Hall, A.J.; Kremmidiotis, G. The vascular disrupting agent BNC105 potentiates the efficacy of VEGF and mTOR inhibitors in renal and breast cancer. Cancer Biol. Ther. 2014, 15, 1552-1560. [CrossRef]

71. Mita, M.M.; Spear, M.A.; Yee, L.K.; Mita, A.C.; Heath, E.I.; Papadopoulos, K.P.; Federico, K.C.; Reich, S.D.; Romero, O.; Malburg, L.; et al. Phase 1 First-in-Human Trial of the Vascular Disrupting Agent Plinabulin (NPI-2358) in Patients with Solid Tumors or Lymphomas. Clin. Cancer Res. 2010, 16, 5892. [CrossRef]

72. Nieddu, V.; Pinna, G.; Marchesi, I.; Sanna, L.; Asproni, B.; Pinna, G.A.; Bagella, L.; Murineddu, G. Synthesis and Antineoplastic Evaluation of Novel Unsymmetrical 1,3,4-Oxadiazoles. J. Med. Chem. 2016, 59, 10451-10469. [CrossRef] [PubMed]

73. Kamal, A.; Shaik, A.B.; Polepalli, S.; Santosh Reddy, V.; Bharath Kumar, G.; Gupta, S.; Rama Krishna, K.V.S.; Nagabhushana, A.; Mishra, R.K.; Jain, N. Pyrazole-oxadiazole conjugates: Synthesis, antiproliferative activity and inhibition of tubulin polymerization. Org. Biomol. Chem. 2014, 12, 7993-8007. [CrossRef] [PubMed]

74. Kamal, A.; Srikanth, P.S.; Vishnuvardhan, M.V.P.S.; Kumar, G.B.; Suresh Babu, K.; Hussaini, S.M.A.; Kapure, J.S.; Alarifi, A. Combretastatin linked 1,3,4-oxadiazole conjugates as a Potent Tubulin Polymerization inhibitors. Bioorganic Chem. 2016, 65, 126-136. [CrossRef] [PubMed]

75. Terenzi, A.; Fanelli, M.; Ambrosi, G.; Amatori, S.; Fusi, V.; Giorgi, L.; Turco Liveri, V.; Barone, G. DNA binding and antiproliferative activity toward human carcinoma cells of copper(II) and zinc(II) complexes of a 2,5-diphenyl[1,3,4]oxadiazole derivative. Dalton Trans. 2012, 41, 4389-4395. [CrossRef]

76. Terenzi, A.; Barone, G.; Piccionello, A.P.; Giorgi, G.; Guarcello, A.; Portanova, P.; Calvaruso, G.; Buscemi, S.; Vivona, N.; Pace, A. Synthesis, characterization, cellular uptake and interaction with native DNA of a bis(pyridyl)-1,2,4-oxadiazole copper(II) complex. Dalton Trans. 2010, 39, 9140-9145. [CrossRef]

77. Jadala, C.; Sathish, M.; Reddy, T.S.; Reddy, V.G.; Tokala, R.; Bhargava, S.K.; Shankaraiah, N.; Nagesh, N.; Kamal, A. Synthesis and in vitro cytotoxicity evaluation of $\beta$-carboline-combretastatin carboxamides as apoptosis inducing agents: DNA intercalation and topoisomerase-II inhibition. Bioorganic Med. Chem. 2019, 27, 3285-3298. [CrossRef]

78. Sathish, M.; Chetan Dushantrao, S.; Nekkanti, S.; Tokala, R.; Thatikonda, S.; Tangella, Y.; Srinivas, G.; Cherukommu, S.; Hari Krishna, N.; Shankaraiah, N.; et al. Synthesis of DNA interactive C3-trans-cinnamide linked $\beta$-carboline conjugates as potential cytotoxic and DNA topoisomerase I inhibitors. Bioorganic Med. Chem. 2018, 26, 4916-4929. [CrossRef]

79. Formagio, A.S.N.; Tonin, L.T.D.; Foglio, M.A.; Madjarof, C.; de Carvalho, J.E.; da Costa, W.F.; Cardoso, F.P.; Sarragiotto, M.H. Synthesis and antitumoral activity of novel 3-(2-substituted-1,3,4-oxadiazol-5-yl) and 3-(5-substituted-1,2,4-triazol-3-yl) ß-carboline derivatives. Bioorganic Med. Chem. 2008, 16, 9660-9667. [CrossRef]

80. Savariz, F.C.; Foglio, M.A.; Goes Ruiz, A.L.T.; da Costa, W.F.; de Magalhães Silva, M.; Santos, J.C.C.; Figueiredo, I.M.; Meyer, E.; de Carvalho, J.E.; Sarragiotto, M.H. Synthesis and antitumor activity of novel 1-substituted phenyl 3-(2-oxo-1,3,4-oxadiazol-5-yl) $\beta$-carbolines and their Mannich bases. Bioorganic Med. Chem. 2014, 22, 6867-6875. [CrossRef] 
81. Petenzi, M.; Verga, D.; Largy, E.; Hamon, F.; Doria, F.; Teulade-Fichou, M.P.; Guédin, A.; Mergny, J.L.; Mella, M.; Freccero, M. Cationic pentaheteroaryls as selective G-quadruplex ligands by solvent-free microwave-assisted synthesis. Chemistry 2012, 18, 14487-14496. [CrossRef]

82. Pirota, V.; Stasi, M.; Benassi, A.; Doria, F. Chapter Six-An overview of quadruplex ligands: Their common features and chemotype diversity. In Annual Reports in Medicinal Chemistry; Neidle, S., Ed.; Academic Press: Cambridge, MA, USA, 2020; Volume 54, pp. 163-196.

83. Doria, F.; Pirota, V.; Petenzi, M.; Teulade-Fichou, M.P.; Verga, D.; Freccero, M. Oxadiazole/Pyridine-Based Ligands: A Structural Tuning for Enhancing G-Quadruplex Binding. Molecules 2018, 23, 2162. [CrossRef] [PubMed]

84. Zhou, K.; Liu, J.; Xiong, X.; Cheng, M.; Hu, X.; Narva, S.; Zhao, X.; Wu, Y.; Zhang, W. Design, synthesis of 4,5-diazafluorene derivatives and their anticancer activity via targeting telomeric DNA G-quadruplex. Eur. J. Med. Chem. 2019, 178, 484-499. [CrossRef] [PubMed]

85. Dalzoppo, D.; Di Paolo, V.; Calderan, L.; Pasut, G.; Rosato, A.; Caccuri, A.M.; Quintieri, L. Thiol-Activated Anticancer Agents: The State of the Art. Anticancer Agents Med. Chem. 2017, 17, 4-20. [CrossRef] [PubMed]

86. Zhao, C.; Rakesh, K.P.; Ravidar, L.; Fang, W.Y.; Qin, H.L. Pharmaceutical and medicinal significance of sulfur (S(VI))-Containing motifs for drug discovery: A critical review. Eur. J. Med. Chem. 2019, 162, 679-734. [CrossRef]

87. Thasneem, C.K.; Biju, C.R.; Babu, G. Synthesis and anticancer study of chalcone linked 1,3,4-oxadiazole derivatives. Int. J. Pharm. Bio. Sci. 2014, 4, 20-28.

88. Vazquez, M.R.; Kantarjian, H.M.; Borthakur, G.M.; O’Brien, S.; Verstovsek, S.; Ravandi, F.; Ferrajoli, A.; Cortes, J.E.; Kadia, T.M.; Wierda, W.G.; et al. A 20-Year Review of Imatinib in Chronic Phase Chronic Myeloid Leukemia Patients after Failure with Interferon Therapy. Blood 2019, 134, 2927. [CrossRef]

89. Li, Y.-T.; Wang, J.-H.; Pan, C.-W.; Meng, F.-F.; Chu, X.-Q.; Ding, Y.-h.; Qu, W.-Z.; Li, H.-Y.; Yang, C.; Zhang, Q.; et al. Syntheses and biological evaluation of 1,2,3-triazole and 1,3,4-oxadiazole derivatives of imatinib. Bioorganic Med. Chem. Lett. 2016, 26, 1419-1427. [CrossRef]

90. Chae, H.-S.; Chin, Y.-W. Anti-allergic effect of lambertianic acid from Thuja orientalis in mouse bone marrow-derived mast cells. Immunopharmacol. Immunotoxicol. 2012, 34, 250-255. [CrossRef]

91. Mironov, M.E.; Pokrovsky, M.A.; Kharitonov, Y.V.; Shakirov, M.M.; Pokrovsky, A.G.; Shults, E.E. Furanolabdanoid-based 1,2,4-oxadiazoles: Synthesis and cytotoxic activity. ChemistrySelect 2016, 1, 417-424. [CrossRef]

92. Markov, A.V.; Sen'kova, A.V.; Popadyuk, I.I.; Salomatina, O.V.; Logashenko, E.B.; Komarova, N.I.; Ilyina, A.A.; Salakhutdinov, N.F.; Zenkova, M.A. Novel 3'-Substituted-1',2',4'-Oxadiazole Derivatives of $18 \beta \mathrm{H}-$ Glycyrrhetinic Acid and Their O-Acylated Amidoximes: Synthesis and Evaluation of Antitumor and Anti-Inflammatory Potential In Vitro and In Vivo. Int. J. Mol. Sci. 2020, 21, 3511. [CrossRef]

93. Hussain, H.; Green, I.R.; Shamraiz, U.; Saleem, M.; Badshah, A.; Abbas, G.; Rehman, N.U.; Irshad, M. Therapeutic potential of glycyrrhetinic acids: A patent review (2010-2017). Expert Opin. Ther. Pat. 2018, 28, 383-398. [CrossRef] [PubMed]

94. Gamal El-Din, M.M.; El-Gamal, M.I.; Abdel-Maksoud, M.S.; Yoo, K.H.; Oh, C.-H. Synthesis and broad-spectrum antiproliferative activity of diarylamides and diarylureas possessing 1,3,4-oxadiazole derivatives. Bioorganic Med. Chem. Lett. 2015, 25, 1692-1699. [CrossRef] [PubMed]

95. Ahsan, M.J.; Sharma, J.; Singh, M.; Jadav, S.S.; Yasmin, S. Synthesis and Anticancer Activity of N-Aryl-5-substituted-1,3,4-oxadiazol-2-amine Analogues. Biomed Res. Int. 2014, 2014, 814984. [CrossRef]

96. Salahuddinm; Mazumder, A.; Shaharyar, M. Synthesis, Characterization, and In Vitro Anticancer Evaluation of Novel 2,5-Disubstituted 1,3,4-Oxadiazole Analogue. Biomed Res. Int. 2014, 2014, 491492. [CrossRef]

97. Srinivas, M.; Satyaveni, S.; Ram, B. Synthesis and Anticancer Activity of 1,2,4-Oxadiazol Linked Benzimidazole Derivatives. Russ. J. Gen. Chem. 2018, 88, 2653-2657. [CrossRef]

98. Gurupadaswamy, H.D.; Girish, V.; Kavitha, C.V.; Raghavan, S.C.; Khanum, S.A. Synthesis and evaluation of 2,5-di(4-aryloylaryloxymethyl)-1,3,4-oxadiazoles as anti-cancer agents. Eur. J. Med. Chem. 2013, 63, 536-543. [CrossRef]

99. Gurupadaswamy, H.D.; Thirusangu, P.; Vijay Avin, B.R.; Vigneshwaran, V.; Prashanth Kumar, M.V.; Abhishek, T.S.; Lakshmi Ranganatha, V.; Khanum, S.A.; Prabhakar, B.T. DAO-9 (2,5-di(4-aryloylaryloxymethyl) -1,3,4-oxadiazole) exhibits p53 induced apoptogenesis through caspase-3 mediated endonuclease activity in murine carcinoma. Biomed. Pharmacother. 2014, 68, 791-797. [CrossRef] 
100. Tiwari, A.; Gopalan Kutty, N.; Kumar, N.; Chaudhary, A.; Vasanth Raj, P.; Shenoy, R.; Mallikarjuna Rao, C. Synthesis and evaluation of selected 1,3,4-oxadiazole derivatives for in vitro cytotoxicity and In Vivo anti-tumor activity. Cytotechnology 2016, 68, 2553-2565. [CrossRef]

101. Mochona, B.; Qi, X.; Euynni, S.; Sikazwi, D.; Mateeva, N.; Soliman, K.F. Design and evaluation of novel oxadiazole derivatives as potential prostate cancer agents. Bioorganic Med. Chem. Lett. 2016, 26, 2847-2851. [CrossRef]

102. Naresh Kumar, R.; Poornachandra, Y.; Nagender, P.; Santhosh Kumar, G.; Krishna Swaroop, D.; Ganesh Kumar, C.; Narsaiah, B. Synthesis of novel nicotinohydrazide and (1,3,4-oxadiazol-2-yl)6-(trifluoromethyl)pyridine derivatives as potential anticancer agents. Bioorganic Med. Chem. Lett. 2016, 26, 4829-4831. [CrossRef]

103. Cascioferro, S.; Attanzio, A.; Di Sarno, V.; Musella, S.; Tesoriere, L.; Cirrincione, G.; Diana, P.; Parrino, B. New 1,2,4-Oxadiazole Nortopsentin Derivatives with Cytotoxic Activity. Mar. Drugs 2019, 17, 35. [CrossRef] [PubMed]

104. Maftei, C.V.; Fodor, E.; Jones, P.G.; Daniliuc, C.G.; Franz, M.H.; Kelter, G.; Fiebig, H.-H.; Tamm, M.; Neda, I. Novel 1,2,4-oxadiazoles and trifluoromethylpyridines related to natural products: Synthesis, structural analysis and investigation of their antitumor activity. Tetrahedron 2016, 72, 1185-1199. [CrossRef]

105. Yadagiri, B.; Gurrala, S.; Bantu, R.; Nagarapu, L.; Polepalli, S.; Srujana, G.; Jain, N. Synthesis and evaluation of benzosuberone embedded with 1,3,4-oxadiazole, 1,3,4-thiadiazole and 1,2,4-triazole moieties as new potential anti proliferative agents. Bioorganic Med. Chem. Lett. 2015, 25, 2220-2224. [CrossRef] [PubMed]

106. Tu, G.; Yan, Y.; Chen, X.; Lv, Q.; Wang, J.; Li, S. Synthesis and antiproliferative assay of 1,3,4-oxadiazole and 1,2,4-triazole derivatives in cancer cells. Drug Discov. Ther. 2013, 7, 58-65. [PubMed]

107. Yonova, I.M.; Osborne, C.A.; Morrissette, N.S.; Jarvo, E.R. Diaryl and Heteroaryl Sulfides: Synthesis via Sulfenyl Chlorides and Evaluation as Selective Anti-Breast-Cancer Agents. J. Org. Chem. 2014, 79, 1947-1953. [CrossRef] [PubMed]

108. Prasanna Kumar, B.N.; Mohana, K.N.; Mallesha, L.; Veeresh, B. Synthesis and in vitro antiproliferative activity of 2,5-disubstituted-1,3,4-oxadiazoles containing trifluoromethyl benzenesulfonamide moiety. Med. Chem. Res. 2014, 23, 3363-3373. [CrossRef]

109. Ertl, P.; Altmann, E.; McKenna, J.M. The Most Common Functional Groups in Bioactive Molecules and How Their Popularity Has Evolved over Time. J. Med. Chem. 2020, 63, 8408-8418. [CrossRef]

110. Khalil, N.A.; Kamal, A.M.; Emam, S.H. Design, Synthesis, and Antitumor Activity of Novel 5-Pyridyl-1,3,4-oxadiazole Derivatives against the Breast Cancer Cell Line MCF-7. Biol. Pharm. Bull. 2015, 38, 763-773. [CrossRef]

111. Zhao, J.-J.; Wang, X.-F.; Li, B.-L.; Zhang, R.-L.; Li, B.; Liu, Y.-M.; Li, C.-W.; Liu, J.-B.; Chen, B.-Q. Synthesis and in vitro antiproliferative evaluation of novel nonsymmetrical disulfides bearing 1,3,4-oxadiazole moiety. Bioorganic Med. Chem. Lett. 2016, 26, 4414-4416. [CrossRef]

112. Bacharaju, K.; Jambula, S.R.; Sivan, S.; JyostnaTangeda, S.; Manga, V. Design, synthesis, molecular docking and biological evaluation of new dithiocarbamates substituted benzimidazole and chalcones as possible chemotherapeutic agents. Bioorganic Med. Chem. Lett. 2012, 22, 3274-3277. [CrossRef]

113. Li, Y.-B.; Yan, X.; Li, R.-D.; Liu, P.; Sun, S.-Q.; Wang, X.; Cui, J.-R.; Zhou, D.-M.; Ge, Z.-M.; Li, R.-T. Discovery of novel heteroarylmethylcarbamodithioates as potent anticancer agents: Synthesis, structure-activity relationship analysis and biological evaluation. Eur. J. Med. Chem. 2016, 112, 217-230. [CrossRef] [PubMed]

114. Weaver, B.A. How Taxol/paclitaxel kills cancer cells. Mol. Biol. Cell 2014, 25, 2677-2681. [CrossRef] [PubMed]

115. Avanzo, R.E.; Padrón, J.M.; D’Accorso, N.B.; Fascio, M.L. Synthesis and in vitro antiproliferative activities of (5-aryl-1,2,4-oxadiazole-3-yl) methyl d-ribofuranosides. Bioorganic Med. Chem. Lett. 2017, 27, 3674-3677; [CrossRef] 
116. Jóźwiak, M.; Filipowska, A.; Fiorino, F.; Struga, M. Anticancer activities of fatty acids and their heterocyclic derivatives. Eur. J. Pharmacol. 2020, 871, 172937. [CrossRef] [PubMed]

117. Hassan, M.F.; Rauf, A.; Sherwani, A.; Owais, M. Synthesis and In Vitro Biological Evaluation of 1,3,4-Oxadiazol-2(3H)-one and Tetrahydropyridazine-3,6-dione Derivatives of Fatty Acids. Sci. Pharm. 2015, 83, 429-443. [CrossRef] [PubMed]

Publisher's Note: MDPI stays neutral with regard to jurisdictional claims in published maps and institutional affiliations.

(C) 2020 by the authors. Licensee MDPI, Basel, Switzerland. This article is an open access article distributed under the terms and conditions of the Creative Commons Attribution (CC BY) license (http://creativecommons.org/licenses/by/4.0/). 